\title{
Cranial morphology of the anguilliform clariid Channallabes apus (Günther, 1873) (Teleostei: Siluriformes): are adaptations related to powerful biting?
}

\author{
Stijn Devaere ${ }^{*}$, Dominique Adriaens ${ }^{1}$, Walter Verraes ${ }^{1}$ and Guy G. Teugels ${ }^{2}$ \\ ${ }^{1}$ University of Ghent, Vertebrate Morphology, K.L. Ledeganckstraat 35, B-9000 Ghent, Belgium \\ ${ }^{2}$ Africa Museum, Ichthyology Department, B-3080 Tervuren, Belgium and KULeuven, Section for Ecology and Systematics, \\ B-3000 Leuven, Belgium \\ (Accepted 22 November 2000)
}

\begin{abstract}
Within the clariids (air-breathing catfish), a complete range of fusiform to anguilliform species can be observed. This study deals with the cranial morphology of Channallabes apus, an extreme anguilliform (eellike) species, compared to the anguilliform Gymnallabes typus and the more fusiform Clarias gariepinus. The overall morphology of the head of Channallabes apus shows a hypertrophied adductor mandibulae complex, with the corresponding substantial narrowing of the neurocranium, seen in the frontals, the sphenotics, the pterotics and the posttemporo-supracleithra, as well as the reduction and displacement of the eyes and some canal bones, such as the infraorbitals and the suprapreopercles. The presence of a hypertrophied muscle complex possibly indicates that a more powerful bite may occur. This implies that adaptations can be expected in several parts of the skull. On the lower jaw of C. apus a higher coronoid process is found, and on the suspensorium, two sets of three processes are present on the hyomandibular bone, indicating a stronger connection to the neurocranium. Several of the observed features, such as the elongation of the body, the reduction of the eyes, the increase in vertebrae number, limblessness and the increasing rigidity of the skull, may also be related to a process of miniaturization.
\end{abstract}

Key words: Siluriformes, Clariidae, Channallabes apus, functional morphology, anguillity

\section{INTRODUCTION}

Catfishes belonging to the family Clariidae are found all over Africa, as well as in the Middle East and parts of Asia (Greenwood, 1961; Teugels, 1996). More generalized species, like Clarias gariepinus (Burchell, 1822) and Heterobranchus longifilis (Valenciennes, 1840) have a wide distribution in Africa, whereas the highly specialized anguilliform (eel-like) species are restricted to Central and West Africa (Boulenger, 1911; Poll, 1957a; Teugels, 1986; Teugels, Denayer \& Legendre, 1990; Teugels, Reid \& King, 1992; Skelton, 1993). It is the latter group of anguilliform genera that makes the clariid family unique among teleost fishes, i.e. an evolutionary transformation exists of fusiform species into anguilliform species, within one family (Pellegrin, 1927). Initially, it was suggested that a gradual trend can be observed in this family, in which the genus Heterobranchus (Geoffrey St-Hilaire, 1809) could be placed at the one end and the anguilliform Dolichallabes (Poll, 1942a) at the other end. This trend not only

*All correspondence to: Stijn Devaere

E-mail: Stijn.Devaere@rug.ac.be involved the striking transformation of both paired and unpaired fins, but also the cranial morphology.

Consequently, a basic morphological description of the skull in several of these anguilliform species was made (David, 1935; Poll, 1942b, 1957b, 1977). These studies demonstrated the presence of a hypertrophied adductor mandibulae complex in all the anguilliform genera, i.e. Playtallabes (Poll, 1944), Platyclarias (Poll, 1977), Gymnallabes (Günther, 1867), Channallabes (Günther, 1873) and Dolichallabes, which could be related to the reduction of several cranial bones. However, a detailed morphological description of these species is still lacking. Previous research has focused on the cranial morphology of Gymnallabes typus (Günther, 1867), in which special adaptations to a powerful closure of the mouth were observed (Cabuy et al., 1999).

Although at first sight, the Clariidae appear to demonstrate a gradual speciation, which involved an increasing anguilliformity (eel-like shape) coupled to a hypertrophy of the adductor mandibulae complex, arguments can be made to support the hypothesis that anguilliformity evolved several times, as well as the fact that anguilliformity is not related to adductor mandibulae morphology. A polyphyletic origin of 
anguilliformity, involving the reduction of paired fins and elongation of the dorsal and anal fin, has already been suggested (Pellegrin, 1927; Poll, 1977). The hypothesis that anguilliformity should not be coupled to adductor mandibulae hypertrophy is, for example, supported by the large muscle complex in the nonanguilliform Tanganykallabes (Poll, 1943). In order to investigate the true nature of the cranial adaptations in those clariid species, the detailed morphology of all those species needs to be studied, thus enabling the discrimination of possible adaptive trends. As part of this research, the cranial morphology of G. typus has been studied, as a representative with extremely large adductor muscles. On the other hand, Channallabes apus (Günther, 1873) is known as one of the most anguilliform species (Pellegrin, 1927), where the adductor muscle appears not to be as strongly developed as in Gymnallabes (Poll, 1942b, 1957a). For that reason, we made a detailed morphological study of the skull of C. apus, paying special attention to adaptations for powerful closure of the mouth.

\section{MATERIAL AND METHODS}

The material examined in the present study was obtained from the Koninklijk Museum voor MiddenAfrika/ Musée Royal de l'Afrique centrale (KMMA), Tervuren, Belgium, as well as from aquarium import. Museum specimens of Channallabes apus (KMMA 175247-270) were collected in the Mbole River (Democratic Republic Congo). For comparison, specimens of Clarias gariepinus and Gymnallabes typus were used. Specimens of G. typus originate from the Nyanga River (Gabon) (KMMA 179111-113), the Odeginni lake (Nigeria) (KMMA 92-083-P-0035-0036), and the Sombreiro River (Nigeria) (KMMA 91-067-01350136).

Descriptions of the cranial morphology of C. gariepinus and G. typus have already been published (Adriaens \& Verraes, 1996, 1997a,c,e, 1998; Adriaens, Verraes \& Taverne, 1997; Cabuy et al., 1999).

The osteology was studied using a total of 4 specimens of C. apus, measuring between 210 and $302 \mathrm{~mm}$ standard length (SL). They were cleared and stained according to a modified protocol of Hanken \& Wassersug (1981) (trypsine being replaced by a $5 \%$ KOH-solution). Three specimens, measuring between 236 and $245 \mathrm{~mm} \mathrm{SL}$, were used to study the external morphology as well as the myology by means of dissection and muscle fibre staining (Bock \& Shear, 1972). Drawings were made with a stereoscopic microscope (Wild M5) with a camera lucida. Specimens of C. gariepinus measured between 126 and $136 \mathrm{~mm} \mathrm{SL}$ (a total of 4 specimens), whereas the 3 specimens of G. typus measured between 217 and $239 \mathrm{~mm}$ total length.

Terminology of the cranial skeleton follows Adriaens \& Verraes (1998), whereas that of the cranial myology follows Winterbottom (1974).
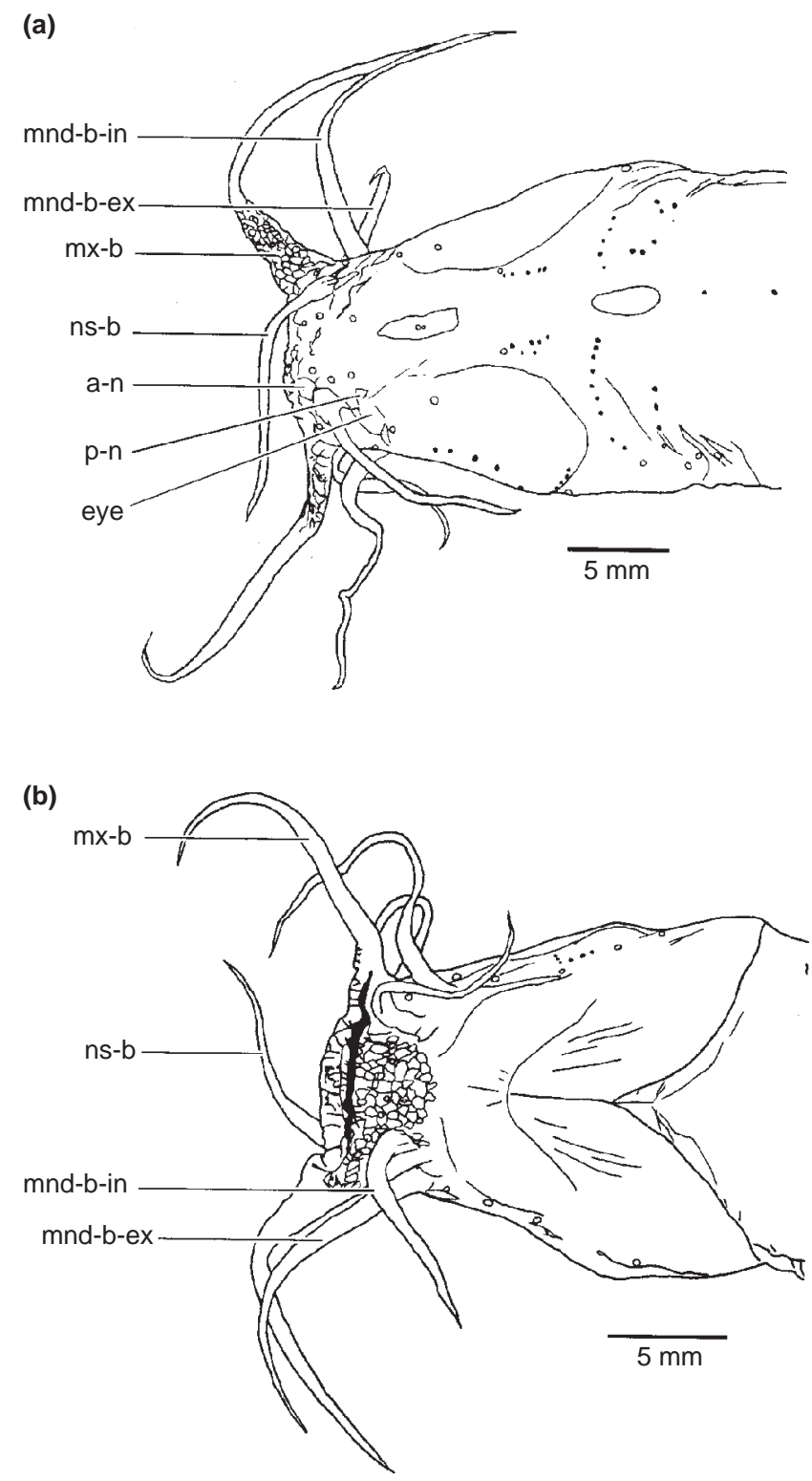

Fig. 1. External morphology of the head of Channallabes apus (236 mm SL) (KMMA 175247-270). (a) dorsal; (b) ventral view of the head. a-n. anterior nostril; mnd-b-ex, external mandibular barbel; mnd-b-in, internal mandibular barbel; mx-b, maxillary barbel; ns-b, nasal barbel; p-n, posterior nostril.

\section{RESULTS}

\section{External morphology}

The preserved specimens of Channallabes apus showed a darkish-brown skin, with the dorsal side being darkest. The degree of anguilliformity can be expressed as the ratio of the total length and body height (Poll, 1942a). In the specimens examined, this ratio lies between 18.6 and 23.6 for C. apus, between 15.4 and 19.6 for G. typus, and between 7 and 9 for $C$. gariepinus. The head length (definition measurements, Teugels, 1986) only comprised between $8.0 \%$ and $9.1 \%$ of the standard length 

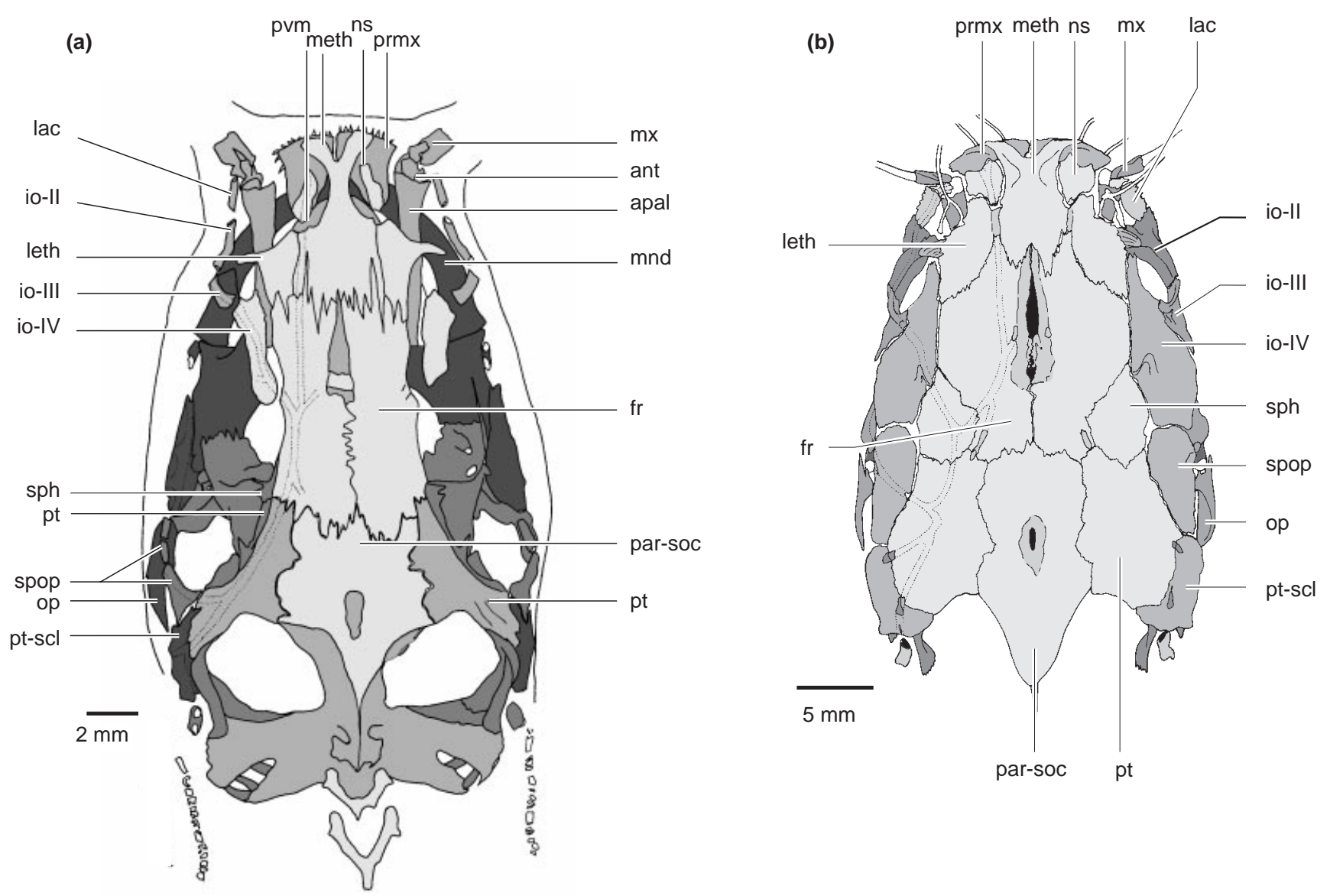

Fig. 2. Dorsal view of the skull of (a) Channallabes apus (258 mm TL) (KMMA 175247-270); (b) Clarias gariepinus (127 mm SL). ant, antorbital; apal, autopalatine; fr, frontal; io-II, infraorbital II; io-III, infraorbital III; io-IV, infraorbital IV; lac, lacrimal; leth, lateral ethmoid; meth, mesethmoid; mnd, mandibula; mx, maxilla; ns, nasal; op, opercle; par-soc, parietosupraoccipital; prmx, premaxilla; pt, pterotic; pt-scl, posttemporo-supracleithrum; pvm, prevomer; sph, sphenotic; spop, suprapreopercular.

in C. apus, between $10.0 \%$ and $11.7 \%$ of the total length in G. typus, and between $26.6 \%$ and $35.0 \%$ of the standard length in C. gariepinus (Teugels, 1986; Cabuy et al., 1999).

Although not bulging out, which is not the case for G. typus, the position of the adductor mandibulae complex can be distinguished as it is hardly covered by bones (Fig. 1). Also compared to G. typus, the snout appears to be more pointed, due to the fact that the skin-folds surrounding the barbel bases is markedly smaller in C. apus (Cabuy et al., 1999, fig. 1). The eyes are largely reduced, compared to $C$. gariepinus, but less than in G. typus. The dorsal fin originates close to the supraoccipital process of the head, and forms a continuous fin-fold, with the anal and caudal fins. No external traces of pectoral or pelvic fins could be discerned.

\section{Cranial skeleton}

\section{Neurocranium}

The narrow neurocranium of $C$. apus consists of a rigid complex of dermal, endo- and periochondral bones
(Fig. 2a). The orbito-temporal region of the skull is markedly less broad than that of C. gariepinus (Fig. 2b), but broader than that of G. typus (Cabuy et al., 1999, fig. 3a).

Ethmoid region: the slender, forked mesethmoid bone supports the underlying premaxillary bones and partially encloses the tubulous nasal bone. From the latter bone, the supraorbital canal continues in-between the lateral ethmoid and the mesethmoid bones into the frontal bones. Three configurations could be discerned in C. apus specimens: (1) the anterior portion of the supraorbital canal not being covered by bone; (2) the anterior portion being covered by a lamellar outgrowth of the mesethmoid; (3) being covered by a lamellar outgrowth of the lateral ethmoid. As in other clariids, the mesethmoid forms the anterior border of the anterior fontanel. The lateral ethmoid bears a pointed, lateral process, which has lost the connection with the second infraorbital bone, compared to C. gariepinus. Ventrally, the lateral ethmoid articulates with the large palatine. The axe-shaped prevomer carries a large, semilunar tooth plate and shows the elongated interdigitation with the parasphenoid, as observed in other clariids. 

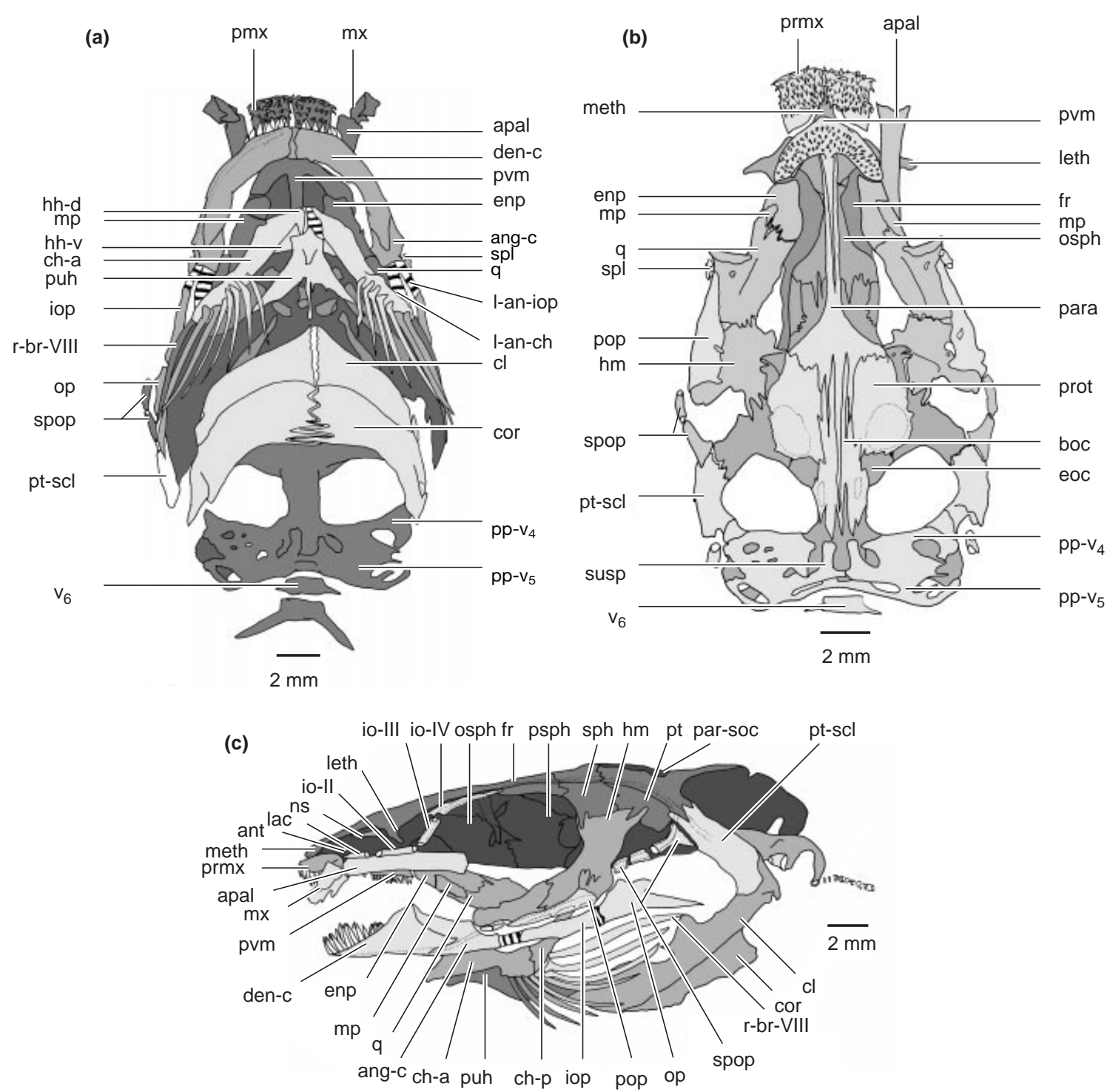

Fig. 3. Skull of Channallabes apus (258 mm SL) (KMMA 175247-270). (a) ventral view of the skull; (b) ventral view of the neurocranium; (c) lateral view of the skull. ang-c, angulosplenio-articuloretroarticular complex; ant, antorbital; apal, autopalatine; boc, basioccipital; ch-a, anterior ceratohyal; ch-p, posterior ceratohyal; cl, cleithrum; cor, coracoid; den-c, dentospleniomentomeckelium complex; enp, entopterygoid; eoc, exoccipital; fr, frontal; hh-d, dorsal hypohyal; hh-v, ventral hypohyal; hm, hyomandibula; iop, interopercle; io-II, infraorbital II; io-III, infraorbital III; io-IV, infraorbital IV; lac, lacrimal; leth, lateral ethmoid; 1-an-ch, ligamentum angulo-ceratohyale; 1-an-iop, ligamentum angulo-interoperculare; meth, mesethmoid; mp, metapterygoid; mx, maxilla; ns, nasal; op, opercle; osph, orbitosphenoid; para, parasphenoid; par-soc, parieto-supraoccipital; pop, preopercle; pp- $\mathrm{v}_{4}$, parapophysis of vertebra 4; pp- $\mathrm{v}_{5}$, parapophysis of vertebra 5; prmx, premaxilla; prot, prootic; psph, pterosphenoid; pt, pterotic, pt-scl, posttemporo-supracleithrum; pvm, prevomer; puh, parurohyal; q, quadrate; r-br-VIII, branchiostegal ray VIII; sph, sphenotic; spl, splenial; spop, suprapreopercle; susp, suspensorium; v $_{6}$, vertebra 6.

Orbital region: the circumorbital series in $C$. apus comprises the antorbital bone and a series of four infraorbital bones, as in C. gariepinus. Most of these bones appear to be tubulous, which is in contrast with C. gariepinus (Fig. 2). Only infraorbital bone IV contains a plate-like extension, although much reduced compared to $C$. gariepinus. The antorbital is a very small bone, lying at the base of the nasal barbel, onto the rostral tip of the palatine. In contrast to $C$. gariepinus, the antorbital did not enclose the rostral part of the infraorbital canal in C. apus. The tubulous lacrimal lies at the level of the olfactory organ, whereas the eye is bordered ventrally by the second and third infraorbitals. The plate-like fourth infraorbital only borders the eye caudally, as the supraorbital process of $C$. gariepinus is lacking. In one specimen, this infraorbital bone was subdivided into two plate-like ossicles. From this infraorbital bone, the infraorbital canal continues into the frontal bone, instead of the dermosphenotic bone as in C. gariepinus as well as in most teleosts (Daget, 1964; 

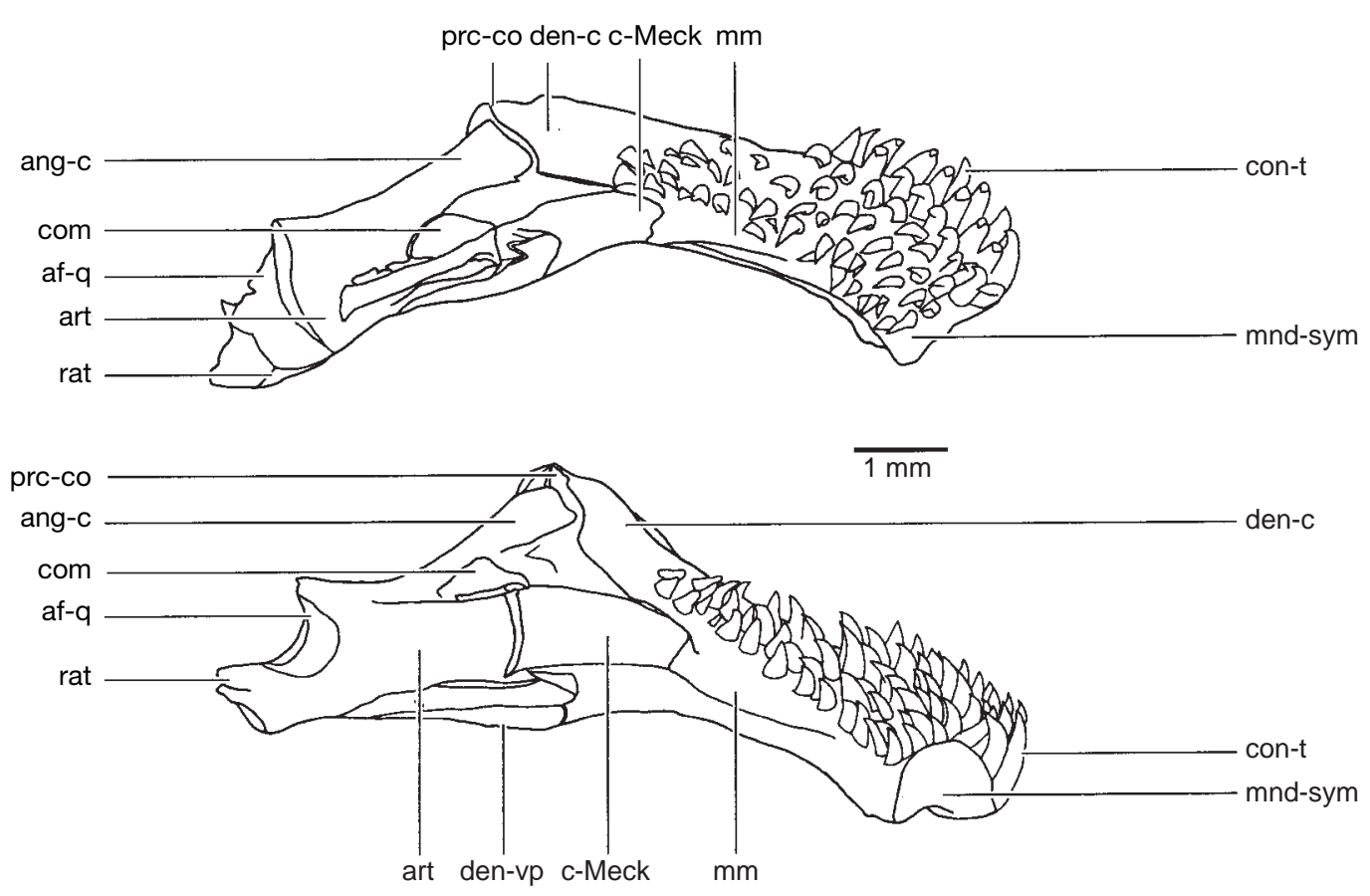

Fig. 4. Dorsal and medial view of the lower jaw of Channallabes apus (258 mm SL) (KMMA 175247-270). af-q, articulatory facet of the angulosplenio-articuloretroarticular with the quadrate; ang-c, angulosplenio-articuloretroarticular complex; art, articular; com, coronomeckelium; con-t, conical teeth; c-Meck, cartilago Meckeli; den-c, dentosplenio-mentomeckelium complex; den-vp, ventral process of the dentosplenio-mentomeckelium; mm, mentomeckelium; mnd-sym, mandibular symphysis; prc-co, coronoid process; rat, retroarticulare.

Gosline, 1975). The latter was also observed in G. typus, as well as in some other specialized siluriforms (Lundberg, 1982). The dermosphenotic bone, however, is strongly reduced, compared to C. gariepinus. The skull roof of the orbitotemporal region is formed by the large frontal bones, which enclose the anterior fontanel. The lateral wall of the skull constitutes the orbitosphenoid and pterosphenoid (synonym pleurosphenoid, Daget, 1964) bones, which are connected to the parasphenoid ventrally.

Temporal region: the skull wall at this level is formed by the sphenotic and pterotic bone complexes, which form the only firm connection between neurocranium and suspensorium. Special adaptations for a firm connection could be observed, as both bone complexes formed distinct processes, which interdigitate with corresponding processes on the suspensorium (Fig. 3b, c). The lateral plates of both the sphenotic and pterotic bones are lacking, as was observed in G. typus, but were much more elaborated in $C$. gariepinus. Ventrally, the brain and labyrinth organ are covered by the parasphenoid and the prootic bones.

Occipital region: the caudal part of the skull roof is formed by the parieto-supraoccipital bone (a fusion of the two bones has been suggested in Fink \& Fink (1996), enclosing a central fontanel (Fig. 2). The latter bears a strongly pointed supraoccipital process, comparable to the one in G. typus, but much more slender than that in $C$. gariepinus. The narrow pterotic bones interconnect the parieto-supraoccipital bone with the post- temporosupracleithral bone, which in turn connects to the pectoral girdle, as well as the parapophyses of the fourth vertebra by means of a solid transscapular process. Ventrally, the occipital region of the skull consists of the exoccipitals, the basioccipitals and small epiotics; the latter however are substantially larger in C. apus and G. typus, compared to C. gariepinus.

\section{Splanchnocranium}

Maxillary bones: the premaxillaries are large, plate-like bones bearing a large number of teeth (Fig. 3). The surface of the latter bone has substantially increased, compared to C. gariepinus (relative to the rest of the skull). In comparison to G. typus, the dentate surface is larger, as dentition ranges closer to the posterior border (Cabuy et al., 1999, fig. 4a). The maxillary bone forms a cup-like bone, which encloses the base of the maxillary barbel and bears two articulatory facets for the articulation with the palatine.

Mandibula: as in other clariids, the lower jaw consists of two parts - the os dentosplenio-mentomeckelium and the os angulosplenio-articuloretroarticulare (Fig 3a, 4). The posterior dental teeth are attached more posteriorly, closer to the base of the coronoid process, which is hardly the case in C. gariepinus. This posterior margin of the tooth series reaches even further in G. typus than in C. apus (Cabuy et al., 1999, fig. 6C). The coronoid process, which is situated at the interdigitation between 


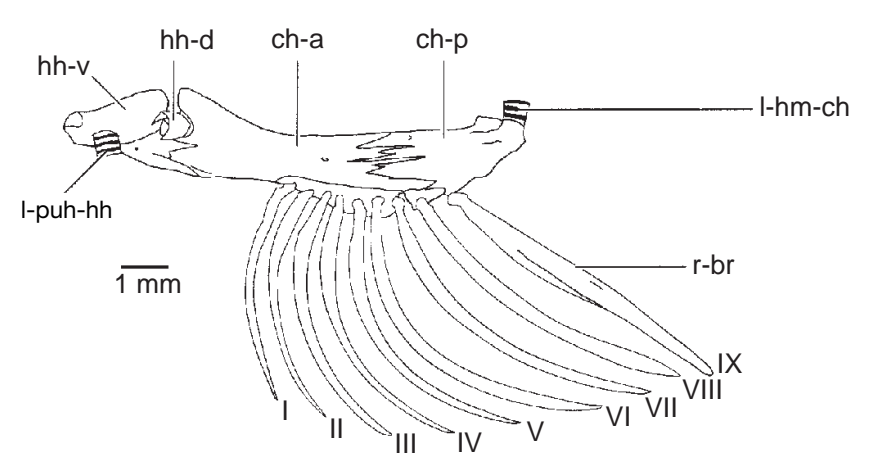

Fig. 5. Medial view of the right hyoid arch of Channallabes apus (230 mm SL) (KMMA 175247-270). ch-a, anterior ceratohyal; ch-p, posterior ceratohyal; hh-d, dorsal hypohyal; hh-v, ventral hypohyal; 1-hm-ch, ligamentum hyomandibuloceratohyale; 1-puh-hh, ligamentum parurohyalo-hypohyale; r-br, radius branchiostegus.

the two mandibular bone complexes, is strikingly larger in C. apus than in C. gariepinus, which is also the case for G. typus. Medially, the Meckel's cartilage lies partially exposed, with the caudal part being covered by the sesamoid coronomeckelian bone. Caudal to the mandibula, a small tubulous ossicle, referred to as the splenial, could be discerned.

Palatine: the rod-like palatine lies ventrally against the lateral ethmoid, with which it articulates. The articulatory facet on the palatine is oval shaped, in contrast to the slender facet in C. gariepinus (Adriaens \& Verraes, 1998, fig. 20C). Anteriorly, the palatine articulates with the modified maxillary bone, being part of the palatine-maxillary mechanism. As in other clariids, both the anterior and posterior tip of the palatine remain cartilaginous.

Hyoid arch: the hyoid arch consists of the two ceratohyals (anterior and posterior) and the two hypohyals (ventral and dorsal) (Fig. 5). The general morphology of the hyoid arch and its components strongly resembles that of C. gariepinus (Adriaens \& Verraes, 1998, fig. 22A). Ventrally, the hyoid arch articulates with eight branchiostegal rays (exceptionally nine). The anterior six (or seven in the case of nine rays) articulate with a ventral rim onto the anterior ceratohyal. The following ray articulates with a ventral cartilaginous region, separating the anterior and posterior ceratohyal, whereas the posterior ray articulates with the posterior ceratohyal (Fig. 3c). To the latter ceratohyal, the ligamenta hyomandibulo-ceratohyale and angulo-ceratohyale are attached. The parurohyal (Fig. 3a) resembles that of other clariids, bearing two lateral and one medial processes. The parurohyal is connected to the ventral hypohyal through the ligamentum parurohyalo-hypohyale. In contrast to $C$. gariepinus, this ligament is odd in C. apus.

Suspensorium: as in most siluriforms, the suspensorium consists of the sesamoid hyomandibula, the quadrate, the metapterygoid, the entopterygoid and the preopercle (Fig. 6). The hyomandibula suspends the
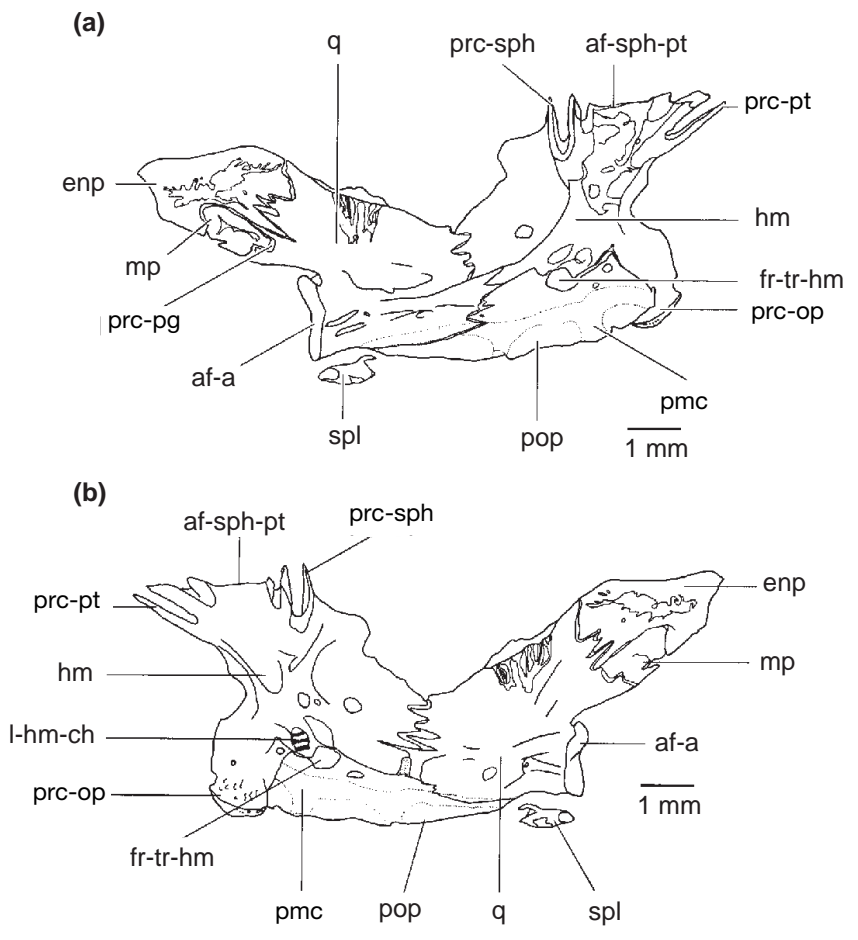

Fig. 6. The left suspensorium of Channallabes apus $(258 \mathrm{~mm}$ SL) (KMMA 175247-270). (a) lateral view; (b) medial view. af-a, articulatory facet of the quadrate with the angulosplenioarticuloretroarticular; af-sph-pt, articulatory facet of the hyomandibula with the sphenotic and the pterotic; enp, sesamoid entopterygoid; fr-tr-hm, foramen truncus hyomandibularis; hm, hyomandibular bone; 1-hm-ch, ligamentum hyomandibulo-ceratohyale; $\mathrm{mp}$, metapterygoid; pmc, preoperculo-mandibular canal; pop, preopercle; prc-op, processus opercular; prc-pg, processus pterygoid of the quadratum; prc-pt, processus pterotic; prc-sph, processus sphenotic; q, quadrate; spl, splenial.

suspensorium with the neurocranium, in relation to which some modifications can be discerned as several anterior and posterior processes have formed. In between these two sets of processes, lies the slender and short articulatory facet of the hyomandibula. The anterior ones fit into similar processes of the sphenotic, whereas the posterior ones fit into gaps into the pterotic (Fig. 3b). At the anterior margin of the perichondral part, the hyomandibula bears a large, bony plate, as was also observed in other clariids. Ventrally, the hyomandibula interdigitates with the preopercle, thereby bordering the foramen of the hyomandibular truncus (Fig. 6). The opercular process of the hyomandibula is markedly directed ventrally, comparable to the situation in G. typus, but more ventrally than in C. gariepinus. Medially, the hyomandibula bears a bony ridge for the attachment of the ligamentum hyomandibuloceratohyale. The quadrate is comparable to that of other clariids, except for the rostral part. In C. apus, the quadrate interdigitates with both the entopterygoid and the metapterygoid, whereas in other clariids, the connec- 
(a)

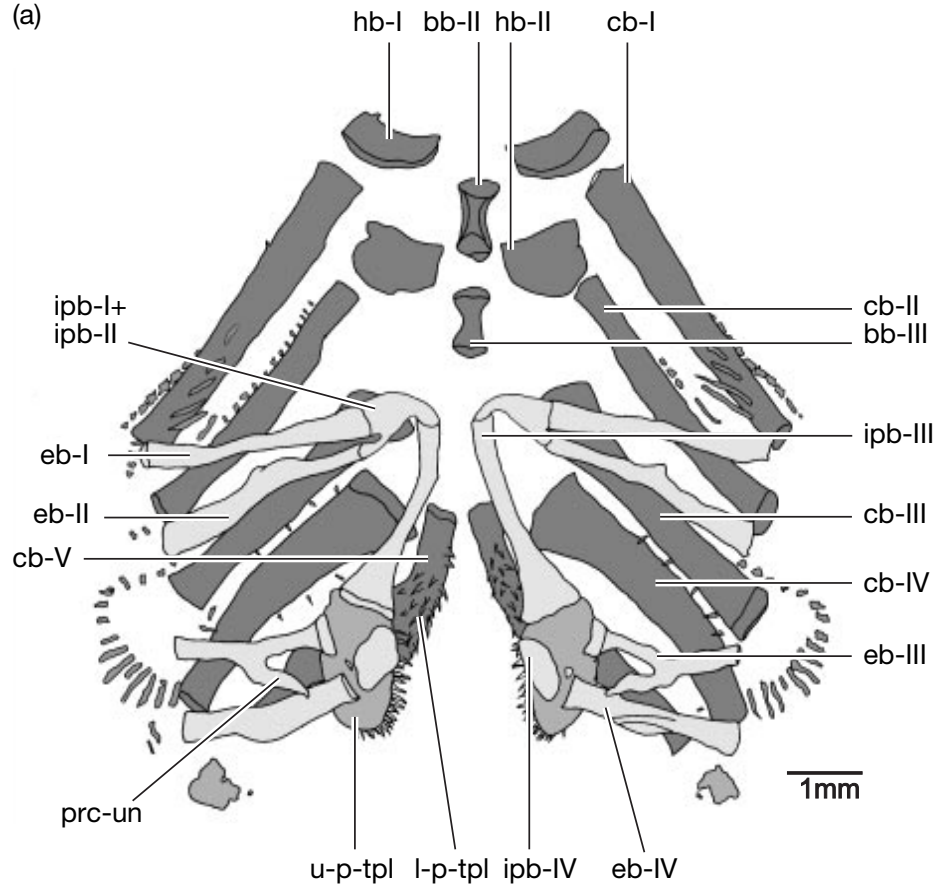

(b)

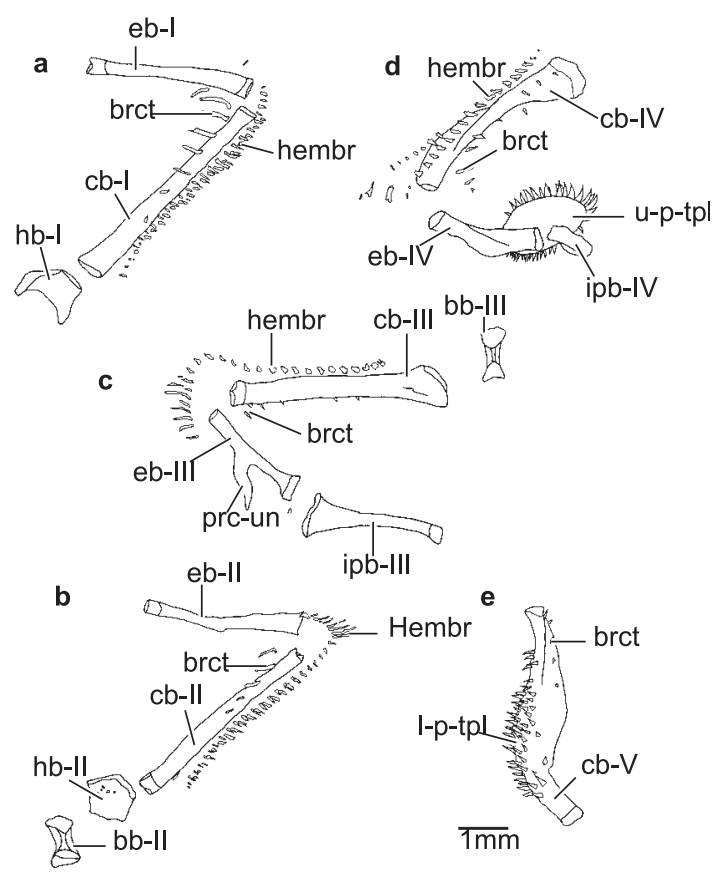

Fig. 7. The branchial arches of Channallabes apus (258 mm SL) (KMMA 175247-270). (a) dorsal view of the entire branchial skeleton; (b) the left branchial arches: dorsal view of: a, branchial arch I; b, branchial arch II; c, branchial arch III; d, branchial arch IV; e, branchial arch V; bb-II, basibranchial II; bb-III, basibranchial III; brct, branchictenium; cb-I, ceratobranchial I; cb-II, ceratobranchial II; cb-III, ceratobranchial III; cb-IV, ceratobranchial IV; cb-V, ceratobranchial V; eb-I, epibranchial I; eb-II, epibranchial II; eb-III, epibranchial III; eb-IV, epibranchial IV; hb-I, hypobranchial I; hb-II, hypobranchial II; hembr, hemibranchium; ipb-I, infrapharyngobranchial I; ipb-II, infrapharyngobranchial II; ipb-III, infrapharyngobranchial III; ipb-IV, infrapharyngobranchial IV; 1-p-tpl, lower pharyngeal tooth plate; prc-un, processus uncinatus; u-p-tpl, upper pharyngeal tooth plate.

tion with the entopterygoid is absent. This quadrateentopterygoid suture spans almost over three-quarters of the suspensorial width at that level, which is consequently reflected in the absence of the dorsal, platelike extension of the metapterygoid, observed in other clariids. Medially, a non-ossified symplectic cartilage can be observed, in between the quadrate and hyomandibular bones (Fig. 6b). The articulatory facet, for the articulation with the mandibula, is markedly larger in $C$. apus, compared to C. gariepinus. As already mentioned, the metapterygoid is small in C. apus, as it mainly consists of the perichondral part. As in other clariids, the connection with the quadrate is through a synchondrosis, whereas that with the entopterygoid is ligamentous and sutures are lacking. The plate-like entopterygoid strongly interdigitates with the quadrate, a feature observed in some other clariids (e.g. Clariallabes, Heterobranchus) (David, 1935). Anteriorly, the entopterygoid is connected ligamentously to the prevomer, the palatine and the lateral ethmoid, thus corresponding to a sesamoid 'entopterygoid type 4' (Arratia, 1992).

Branchial arches: the 'Bauplan' (terminology: Verraes, 1981) of the branchial basket corresponds to the general clariid situation (Fig. 7), with the exception of the number and size of the gill rakers. These gill rakers are smaller, both in size and number in C. apus, compared to C. gariepinus and even compared with G. typus. For a detailed description of this general configuration, we refer to Adriaens \& Verraes (1998).

\section{Opercular series}

The opercular bone is a pointed, triangular bone, bearing a large articulator facet for articulation with the suspensorium (Fig. 3c). Dorsal to this articulator facet, the opercular bone bears a plate-like process, onto which some of the opercular muscles are attached (see below). The posterior part of this bone consists of a horizontal ridge (for the attachment of the opercular levator muscle), as well as a small ventral plate. As in most other teleosts, the opercular is ligamentously connected to the interopercular bone (Daget, 1964). The latter bone is comparable to that of other clariids, including the ligamentous connection with the lower jaw. As already mentioned, the preopercular bone is firmly connected to the suspensorium, as it encloses the preoperculo-mandibular canal (Fig. 6). The caudal part of the latter canal is enclosed in a series of small suprapreopercular bones, of which the proximal ones are tubulous. The number of suprapreopercular bones ranged from two to three, with the distal one always bearing a plate-like extension. As in G. typus, the 
(a)

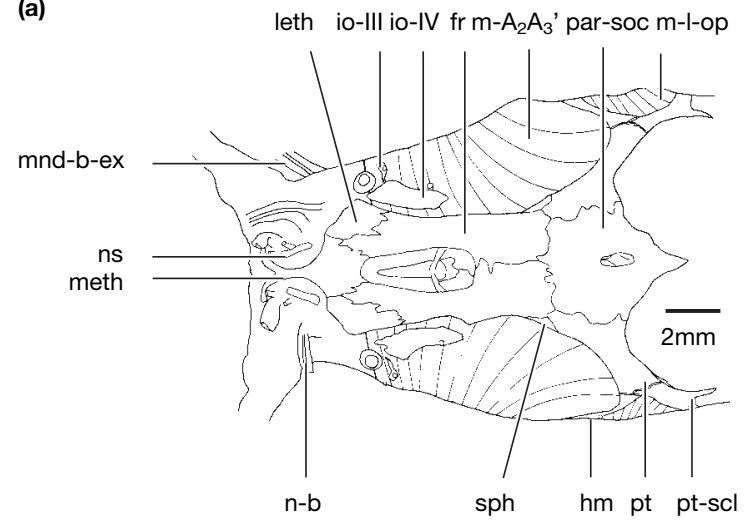

(b)

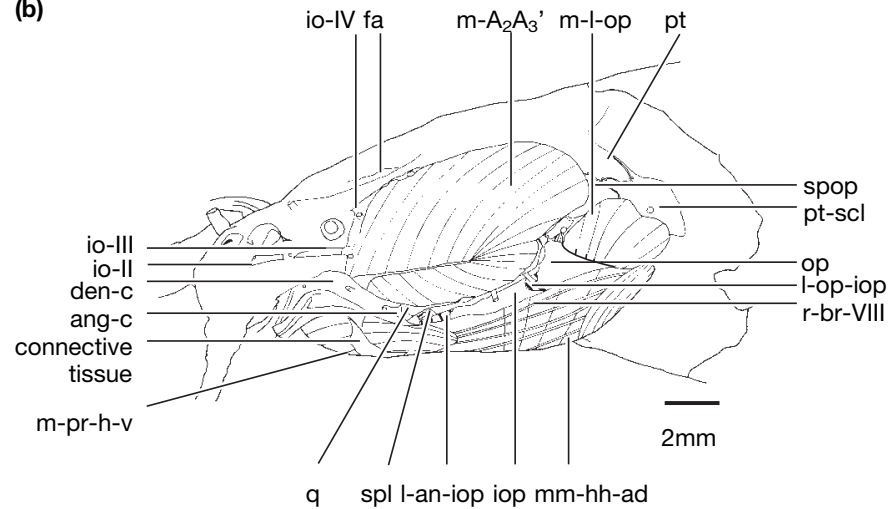

(c)

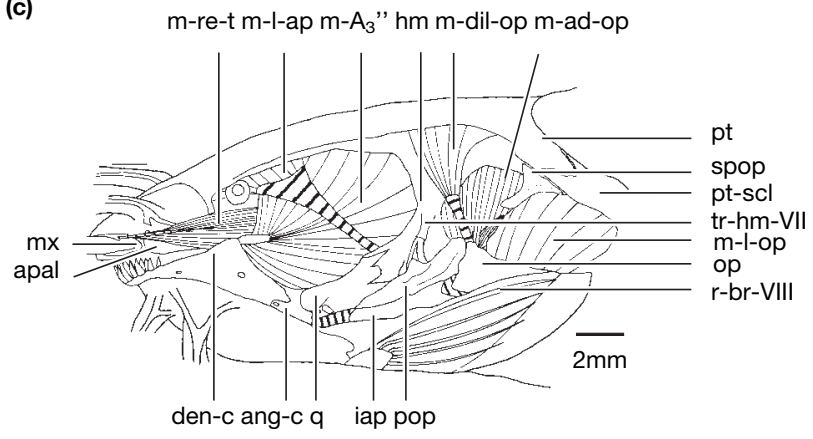

(d)

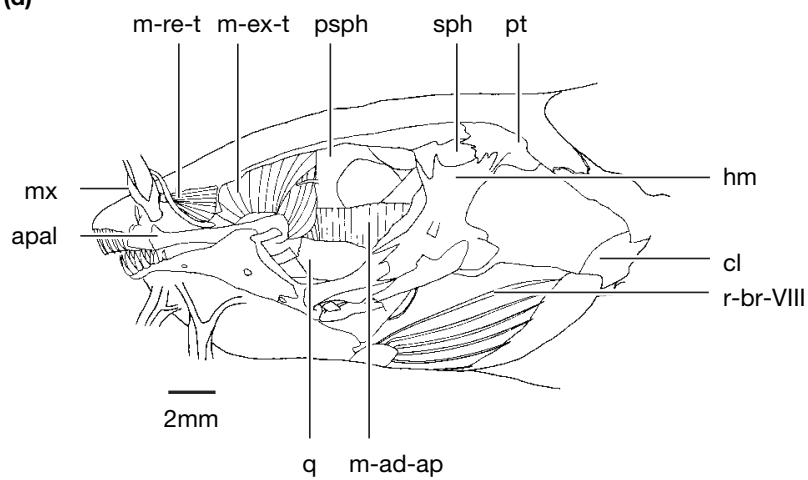

Fig. 8. The head musculature of Channallabes apus (236 mm SL) (KMMA 175247-270). (a) dorsal view, skin and barbels are removed; (b) lateral view, skin and barbels are removed; (c) lateral view, external jaw muscle is removed; (d) lateral view, internal jaw muscle and the opercular muscles are removed. ang-c, angulosplenio-articuloretroarticular complex; apal, autopalatine; cl, cleithrum; den-c, dentosplenio-mentomeckelium complex; fr, frontal; hm, hyomandibula; iop, interopercle; io-II, infraorbital II; io-III, infraorbital III; io-IV, infraorbital IV; leth, lateral ethmoid; 1-an-iop, ligamentum angulo-interoperculare, 1-op-iop, ligamentum operculo-interopercle; meth, mesethmoid; mm-hh-ad, musculi hyohyoidei adductores; mnd-b-ex, external mandibular barbel; $\mathrm{mx}$, maxilla; $\mathrm{m}-\mathrm{A}_{2} \mathrm{~A}_{3}{ }^{\prime}$, musculus adductor mandibulae $\mathrm{A}_{2} \mathrm{~A}_{3}{ }^{\prime} ; \mathrm{m}-\mathrm{A}_{3}{ }^{\prime \prime}$, musculus adductor mandibulae $\mathrm{A}_{3}{ }^{\prime \prime} ; \mathrm{m}-\mathrm{ad}-\mathrm{ap}$, musculus adductor arcus palatini; $\mathrm{m}$-ad-op, musculus adductor operculi; $\mathrm{m}$-dil-op, musculus dilatator operculi; $\mathrm{m}$-ex-t, musculus extensor tentaculi; m-l-ap, musculus levator arcus palatini; m-l-op, musculus levator operculi; m-pc-h-v, musculus protractor hyoidei pars ventralis; m-re-t, musculus retractor tentaculi; ns, nasal; n-b, nasal barbel; op, opercle; par-soc, parietosupraoccipital; psph, pterosphenoid; pop, preopercle; pt, pterotic; pt-scl, posttemporo-supracleithrum; q, quadrate; r-br-VIII, branchiostegal ray VIII; sph, sphenotic; spl, splenial; spop, suprapreopercle; tr-hm-VII, truncus hyomandibularis nervus facialis.

surface covered by the suprapreopercular bones is much reduced, compared to the situation in $C$. gariepinus. From the distal suprapreopercular bone, the preopercular canal continues into the pterotic bone.

\section{Cranial myology}

\section{Muscles of the lower jaw}

M. adductor mandibulae: the adductor mandibulae of C. apus is an enormous muscle complex, covering almost the entire lateral side of the skull (Fig. 8a, b). It consists, as in other clariids studied, of an external $\mathrm{A}_{2} \mathrm{~A}_{3}{ }^{\prime}$-part and an internal $\mathrm{A}_{3}{ }^{\prime \prime}$-part (terminology: Vetter, 1878), which are separated by the levator arcus palatini (Adriaens \& Verraes, 1996). The bipinnate $\mathrm{A}_{2} \mathrm{~A}_{3}{ }^{\prime}$ muscle forms the largest part of the complex, with its tendon inserting onto the lower jaw, at the level of the coronoid process. The fibres of the dorsal $\mathrm{A}_{2} \mathrm{~A}_{3}{ }^{\prime} \alpha$ run more vertically, whereas those of the ventral $\mathrm{A}_{2} \mathrm{~A}_{3}{ }^{\prime} \beta$ lie more horizontally. Anteriorly, the dorsal part of the adductor complex is attached directly to the infraorbitale IV, the frontal, the sphenotic, the pterotic, the suprapreopercle bones and the posttemporo-supracleithrum. The ventral $\mathrm{A}_{2} \mathrm{~A}_{3}{ }^{\prime} \beta$ inserts onto the lateral side of the suspensorium: the quadrate, the preopercle and the hyomandibula. The $\mathrm{A}_{2} \mathrm{~A}_{3}$ ' covers the levator arcus palatini, the dilatator operculi and the adductor operculi. The complete covering of the latter two muscles could also be observed in G. typus, but was only partial in $C$. gariepinus.

The deeper part of the complex, the $\mathrm{A}_{3}{ }^{\prime \prime}$, is linked to the neurocranium and the suspensorium (Fig. 8c). As in other clariids, the $\mathrm{A}_{3}{ }^{\prime \prime}$ can be divided in a lateral pars 
(a)

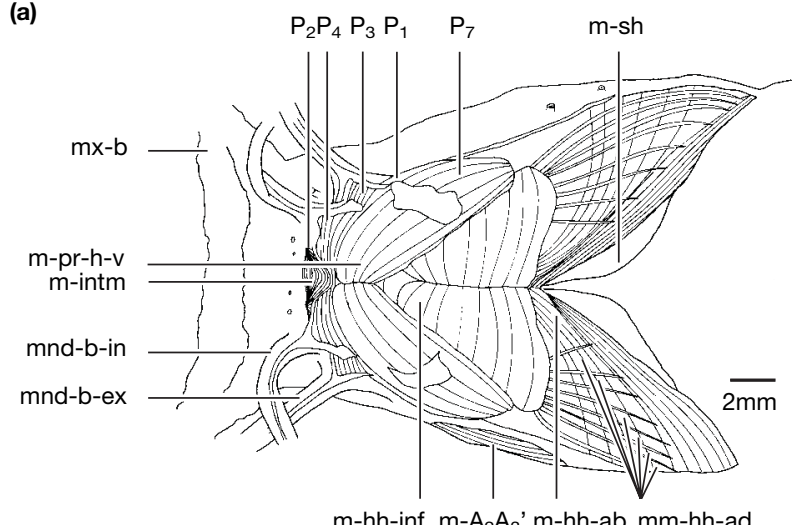

(b)

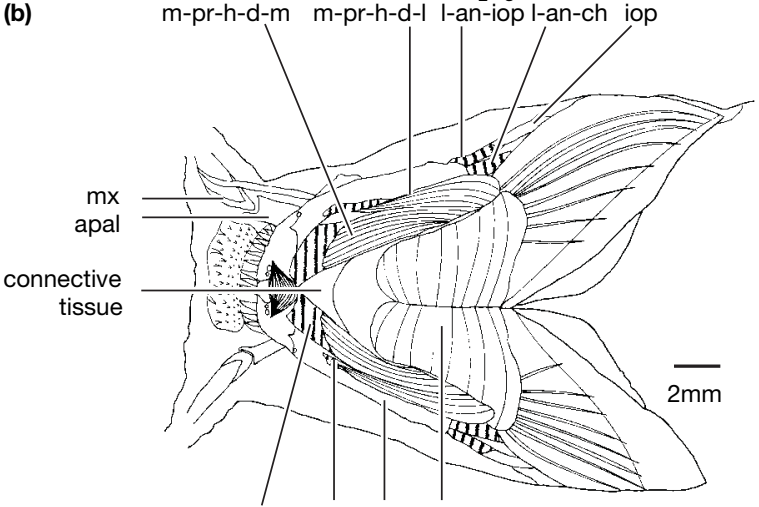

t-pr-h-d-m t-pr-h-d-I mnd m-hh-inf (c)

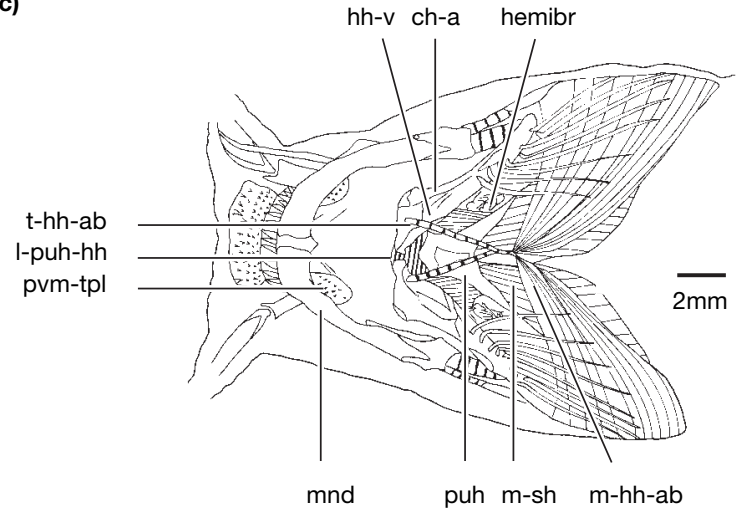

(d)

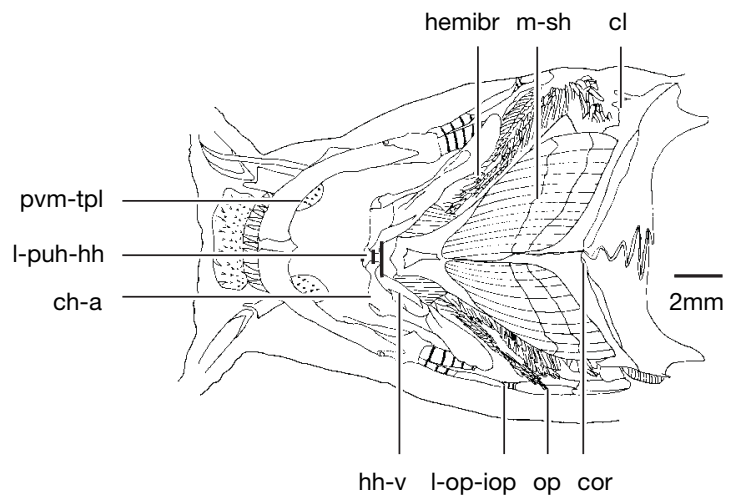

Fig. 9. Ventral view of the head musculature of Channallabes apus (236 mm SL) (KMMA 175247-270). (a) skin and barbels are removed; (b) ventral part of the hyoid protractor is removed; (c) hyoid protractor, intermandibular and hyohyoideus inferior are removed; (d) hyohyoideus abductor and the hyohyoidei adductores are removed. apal, autopalatine; ch-a, anterior ceratohyal; cl, cleithrum; cor, coracoid; hembr, hemibranchium; hh-v, ventral hypohyal; iop, interopercle; 1-an-ch, ligamentum anguloceratohyale; 1-an-iop, ligamentum angulo-interoperculare; 1-op-iop, ligamentum operculo-interoperculare; 1-puh-hh, ligamentum parurohyalo-hypohyale; mnd, mandibular; mnd-b-in, internal mandibular barbel; mnd-b-ex, external mandibular barbel; mx, maxilla; mx-b, maxillary barbel; $\mathrm{m}-\mathrm{A}_{2} \mathrm{~A}_{3}{ }^{\prime}$, musculus adductor mandibulae $\mathrm{A}_{2} \mathrm{~A}_{3}$; $;$ m-hh-ab, musculus hyohyoideus abductor; mm-hh-ad, musculi hyohyoidei adductores; m-pr-h-d-1, musculus protractor hyoidei pars dorso-lateralis; m-pr-h-d-m, musculus protractor hyoidei pars dorso-medialis; m-pr-h-v, musculus protractor hyoidei pars ventralis; m-intm, musculus intermandibularis; m-hh-inf, musculus hyohyoideus inferior; m-sh, musculus sternohyoideus; op, opercle; puh, parurohyale; pvm-tpl, prevomer tooth plate; t-hh-ab, tendon of the m. hyohyoideus abductor; t-pr-h-d-1, tendon of the m. protractor hyoidei pars dorso-lateralis; t-pr-h-d-m, tendon of the $\mathrm{m}$. protractor hyoidei pars dorso-medialis.

superficialis and a medial pars profunda. The pars superficialis forms the largest part, but with a smaller tendon compared to the other one. The insertion occurs onto the frontal, the sphenotic and the pterosphenoid, as well as onto the caudal part of the quadrate and hyomandibular membranous plate. The pars profunda is completely separated from the pars superficialis, as is the case in both $C$. gariepinus and $G$. typus. The vertically directed fibres originate on the hyomandibular membranous plate, inserting tendinously onto the antero-medial side of the angular-complex.

$M$. intermandibularis: this muscle is a short, broad muscle covering the mandibular symphysis, ventral on the rostral ending of the mandibula (Fig. 9a). As in other clariids, the intermandibular muscle is separated from the protractor hyoidei through the interconnecting part of the left and right mandibular barbel base.

\section{Suspensorial muscles}

M. levator arcus palatini: as in other clariids, the levator arcus palatini is a thin muscle sheet, interconnecting the lateroventral ridge of the neurocranium with the suspensorium, thereby separating the two major parts of the adductor mandibulae complex (Fig. 8c). Compared to other clariids, this levator is much reduced in C. apus, although in all of them, the origin is spread over the lateroethmoid and the frontal bones. It is constituted of a tendinous part for more than three quarters of its length (in $C$. gariepinus, this is only half of the muscle) (Adriaens \& Verraes, 1997d, fig. 7b). Compared to $C$. gariepinus and G. typus, however, the levator muscle has become much smaller. As a result, the posteriormost fibers originate from the frontal bone, at the level of the mandibular articulation (whereas in the other 
species these fibres lie well posterior to that articulation). The long tendon inserts onto the anterior perichondral part of the hyomandibula.

M. adductor palatini: the adductor arcus palatini connects the neurocranium with the dorsal rim of the suspensorium (Fig. 8d). The muscle fibres originate mainly on the lateral side of the parasphenoid but also on the orbito- and pterosphenoid. The insertion on the suspensorium is spread over the quadrate and hyomandibular membranous plates, as well as the entopterygoid. Due to the direct connection between the entopterygoid and the quadrate, the insertion onto the metapterygoid is lost in C. apus.

\section{Opercular muscles}

M. dilatator operculi: the flattened dilatator operculi originates from the frontal, the sphenotic, the pterotic and the dorsal part of the hyomandibula. The fibres attach through a long and narrow tendon to the dorsal processus of the opercle, close to the articulation with the hyomandibula and lateral to the insertion of the adductor operculi. Whereas in C. gariepinus and in $G$. typus the anterior dilatator fibres contact the posterior fibres of the levator arcus palatini, both are well separated in C. apus, as a result of the narrowing of the latter muscle. The dilatator seems to positioned (or tilted) more posteriorly as well, as it no longer covers the caudal part of the $\mathrm{A}_{3}{ }^{\prime \prime}$ and it inserts onto the pterotic, which is not the case in C. gariepinus or in G. typus.

M. adductor operculi: the adductor operculi connects the dorsocaudal ridge of the hyomandibula to the opercle. It is attached to the connective tissue covering the suprabranchial cavity, as well as to the suprapreopercular bone and the ventral side of the pterotic. This muscle attaches musculously to the dorsal process of the opercular bone, where the fibers join the dilatator operculi tendon.

M. levator operculi: the levator operculi is the largest, caudally situated opercular muscle, which connects the opercle with the neurocranium. The muscle originates from the rostral ridge of the postemporo-supracleithrum, the caudolateral rim of the pterotic, the suprapreopercular bone and the connective tissue covering the dorsoventral side of the suprabranchial cavity. Ventrally, the levator inserts on the dorsal side of the opercle.

\section{Maxillary barbel muscles}

M. retractor tentaculi: the retractor tentaculi enables the retraction of the maxillary bone, as it connects the latter bone to the suspensorium. It runs in-between the $\mathrm{A}_{3}{ }^{\prime \prime}$ and the adductor arcus palatini. The muscle originates from the quadrate and hyomandibular membranous plate, and insert through a long tendon on the posterodorsal side of the maxillary bone (Fig. 8c).

M. extensor tentaculi: the extensor tentaculi connects the ventral and ventrolateral side of the lateroethmoid, the ventral side of the frontal and the lateral side of the orbito- and pterosphenoid to the autopalatinum. All fibres insert musculously on the autopalatinum, caudal to its articulatory facet. In C. gariepinus the extensor tentaculi consists of a medial part connected to the metapterygoid and a lateral part connected to the neurocranium (Adriaens \& Verraes, 1997c).

\section{Hyoid muscles}

M. protractor hyoidei: the hyoid bars are connected to the lower jaw through the large, compact protractor hyoidei (Fig. 9a). As in other clariids, a ventral and a dorsal part could be discerned. Comparable to the situation in G. typus, the left and right dorsal parts are separated and attached to the lower jaw through an aponeurosis, thus differing from C. gariepinus (Adriaens \& Verraes, 1997b, fig. 6B). However, in C. apus, the aponeuroses are markedly larger than in G. typus (Cabuy et al., 1999, fig. 8B). Both the ventral and dorsal parts originate on the ventrolateral side of the anterior ceratohyal. In relation to the mandibular barbel control, several fields can be discerned in the ventral part of the hyoid protractor.

$M$. hyohyoideus inferior: the hyohyoideus inferior is a massive muscle, covering the ventral side of the contralateral anterior ceratohyals and ventral hypohyals (Fig. 9a, b). Caudo-laterally, it is also connected to the bases of the branchiostegal rays, this in contrast to G. typus and C. gariepinus. A subdivision into a pars caudalis and a pars rostralis, as observed in G. typus is absent in C. apus.

M. hyohyoideus abductor: the hyohyoideus abductor links the rostral tip of the hyoidbar with the first contralateral branciostegal rays (Fig. 9a-c). The muscles originate from the rostral face of this branchiostegal ray, and insert tendinously onto the ventral hypohyal of the opposite side, as observed in other clariids.

Mm. hyohyoidei adductores: the hyohyoidei adductor muscles form a series of sheets between consecutive branchiostegal rays, starting from the first one and ending onto the medial side of the opercular bone (Fig. 9a-c).

M. sternohyoideus: the sternohyoideus forms a broad muscle between the pectoral girdle and the hyoidbars, by means of the parurohyal (Fig. 9a-d). As in C. gariepinus, both the medial fibres of the middle myomere, as well as those of the caudal myomere attach to the cleithrum (Adriaens \& Verraes, 1997b). Anteriorly, the muscle heads fit into the double-forked parurohyal bone, which in turn is ligamentously connected to the ventral hypohyals.

\section{DISCUSSION}

Compared with a generalized clariid species, Clarias gariepinus, the overall morphology of the skull in 
Channallabes apus shows the hypertrophied adductor mandibulae complex, with a corresponding, substantial narrowing of the neurocranium. In general, this corresponds to the shape changes observed in other anguilliform clariids, like Gymnallabes typus (Cabuy et al., 1999). The narrowing of the skull provides additional space for the hypertrophied muscle, thereby taking into account the spatial constraints within the design. Additional space is also provided by the reduction of the eyes, as well as the reduction of the infraorbitales bones (Barel, 1984). A large adductor mandibulae complex may be seen as an adaptation to powerful biting. However, simply enlarging the muscle will not be sufficient - structural adaptations for coping with the related increase in mechanical load have to be provided in order to avoid damaging the skull. As a consequence of the reinforcement of the mouth closing apparatus, special adaptations for mouth opening may be present as well.

\section{A hypertrophied adductor mandibulae complex}

Hypertrophy of the adductor mandibulae complex has been observed in several species of the Clariidae, especially in the extreme anguilliform species G. typus and Dolichallabes microphthalmus (Poll, 1942) (Poll, 1957b, 1977). Hypertrophy of these mouth closing muscles, however, has also been noted in other teleosts, such as the Mastacembelidae (Travers, 1984) and Synbranchidae (Liem, 1980), as well as in other vertebrates (e.g. the sexual dimorphism in primate fossils, reflected in the presence of a sagittal ridge on the skull) (Benton, 1997).

The hypertrophy of the mandibular adductor muscle does not involve an increase in its complexity, as it closely resembles that of $C$. gariepinus (Adriaens \& Verraes, 1996). In contrast to the extreme complex adductor mandibulae in bagrids, only an $\mathrm{A}_{2} \mathrm{~A}_{3}{ }^{\prime}$ and two $\mathrm{A}_{3}{ }^{\prime \prime}$-parts could be discerned (Diogo et al., 1999). The major part of the adductor mandibulae complex is formed by the large $\mathrm{A}_{2} \mathrm{~A}_{3}{ }^{\prime}$, which covers the other parts of the adductor completely, as well as other muscles (e.g. the levator arcus palatini and dilator operculi) and skeletal elements (e.g. the suspensorium) (Fig. 8a). Although in C. gariepinus, it is only the dorsal fibres of the dorsal part of $\mathrm{A}_{2} \mathrm{~A}_{3}{ }^{\prime}$ that are markedly elongated, in $C$. apus, as well as in G. typus, the whole dorsal part reaches substantially more posteriorly. Consequently, in the latter two species, the $\mathrm{A}_{2} \mathrm{~A}_{3}{ }^{\prime}$ borders against the levator operculi, thus completely covering the dilatator and adductor operculi muscles. As a result of the increased height (relative to the length), the range of fibre directions is much increased in the anguilliform species, G. typus and C. apus, compared to C. gariepinus. In Clariallabes, which represents an intermediate configuration, an increase in the height can already be observed, compared to C. gariepinus (Cabuy et al., 1999). This increase also implies that the rostralmost insertion of the $\mathrm{A}_{2} \mathrm{~A}_{3}{ }^{\prime}$ shifted more anteriorly, resulting in the fact that the anterior fibres of the dorsal part of the $\mathrm{A}_{2} \mathrm{~A}_{3}{ }^{\prime}$ are directed more vertically.
The medial part of the complex, the $\mathrm{A}_{3}$ " comprises a superficial and a deeper muscle (i.e. the pars superficialis and pars profunda, respectively) (Fig. 8c). The same subdivision, as well as the fact that $\mathrm{A}_{2} \mathrm{~A}_{3}{ }^{\prime}$ and $\mathrm{A}_{3}{ }^{\prime \prime}$ are separated by a levator arcus palatini, can be observed in all other clariids studied (Adriaens \& Verraes, 1996; Cabuy et al., 1999). The subdivision of the complex by the levator arcus palatini can also be observed in many other teleosts (Winterbottom, 1974). Compared to C. gariepinus, the superficial part is much larger in C. apus, as well as in G. typus. In both species, a dorsal set of fibres seems to be added, which inserts onto the dorsal part of the $\mathrm{A}_{3}$ " tendon. In C. gariepinus, the tendon continues into the dorsal most fibres, whereas in C. apus and G. typus, it continues into the medial fibres (Fig. 8c). In analogy to the $\mathrm{A}_{2} \mathrm{~A}_{3}{ }^{\prime}$ muscle, this implies that the range of fibre directions is also increased in this part of the $\mathrm{A}_{3}$ ".

The morphology of the deeper part of $\mathrm{A}_{3}$ " seems to be less variable in clariids, as in C. apus, G. typus and C. gariepinus, the muscle is a small bundle with dorsoventrally directed fibers.

\section{Spatial constraints within the integrated design}

The spatial constraints within an integrated design imply that trade-offs will occur (Barel, 1984). The expansion of the adductor mandibulae complex can thus be expected to be related to spatial changes in the surrounding structures, in all three dimensions of the 'Bauplan' framework.

The results of this paper do not provide evidence that allows directional interpretations of causalities and consequences. The assumptions made in the following discussion have to be considered as a reflection of what may be the logic behind the spatial interactions that must have occurred in the cranial Bauplan.

The reflections are based on the assumption that the driving force in terms of fitness must have been related to the trophic advantage of larger jaw muscles. Other adaptations can be regarded in this context, without necessarily knowing the exact causal/morphogenic relationship.

Relations to the expansion of the adductor mandibulae complex in the lateromedial direction, are manifested in the narrowing of the central part of the neurocranium, as well as the reduction and displacement of canal bones. Compared to C. gariepinus, both the skull roof and the skull floor are much narrower in C. apus, although less narrow than in G. typus. The reduction of the skull roof appears to be concentrated in the orbitotemporal and oticoccipital regions. This largely involves the reduction of the lateral plate-like extensions of the frontals, the sphenotics, the pterotics and the posttemporo-supracleithra (Fig. 2) (Cabuy et al., 1999, fig. 3). Whereas in G. typus the complete lateral parts, extending beyond the lateral walls of the skull, are absent, a small rim can still be distinguished in C. apus. The narrowing in the ethmoid region is less 
pronounced, as a comparable constriction can be observed in all three, non-generalized species (C. melas, $C$. apus and G. typus). In G. typus, which shows the most constricted skull roof, the narrowing of the skull starts in the lateral ethmoid and stops in the frontal, at the level of the contact with the posterior infraorbitals (Cabuy et al., 1999, fig. 3a). In the three above mentioned species, the forked tip of the mesethmoid and the premaxillaries are of comparable shape, although markedly more narrow than that of C. gariepinus. However, the overall increasing skull narrowing is coupled to a caudal extension of the premaxillaries. Whereas in G. typus, this only involves the extension of the edentulous part, in $C$. apus the tooth battery is distinctly expanded caudally (Fig. 3b).

In the dorsoventral direction (as well as the anteroposterior direction), the muscle hypertrophy is coupled to the separation and reduction of the dermal, plate-like bones covering the adductor mandibulae complex in C. gariepinus. A broad range in the degree of such separations and reductions have frequently been observed in many other clariid species (including the genus Clarias), and is used as an important taxonomic character (Poll, 1957a; Teugels, 1986; Caroll, 1988). The impact of the adductor mandibulae complex enlargement is manifested both anteriorly and posteriorly. Anteriorly, the eye has been substantially reduced, coupled to the fact that it has been shifted slightly anteriorly. Also, the infraorbital series is much reduced. The anterior ones are tube-like, whereas the posterior ones have lost the posterior plate-like extension, thus providing space for the expanded muscle. As a consequence, the eye can no longer be supported by the second infraorbital, which is the case in C. gariepinus. However, due to substantial reduction in eye size, this is no longer necessary. In G. typus, which has the smallest eyes and the largest adductor complex, the infraorbitals are the most reduced, as all of them are tubulous (Cabuy et al., 1999, fig. 3a). Posteriorly, the relation to the muscle hypertrophy is situated at the level of the suprapreopercular bones. The shape changes are analogous to those in the infraorbitals: (1) the suprapreopercular bones have shifted away from the muscle (thus caudally in this case); (2) the distal bones have become tubulous; (3) the proximal one has only lost that part of the plate-like extension close to the adductor mandibulae complex (Fig. 2a). As a result of the rostral and caudal displacement of the infraorbital and suprapreopercular bones, respectively, the corresponding lateral line canals have shifted as well. The infraorbital canal no longer exits the dermosphenotic bone but leaves the frontal bone. The branch to the preopercular canal is displaced caudally, coupled to an elongation of the pterotic bone, and the canal is directed caudally (in contrast to laterorostrally in C. gariepinus). The same trend can be observed in the other clariids studied.

In the anteroposterior direction, the accommodation for the enlarged adductor muscle is related to the reduction and displacement of the above mentioned infraorbitals and suprapreopercular bones. Other substantial skeletal transformations or displacements appeared not to be essential for this accommodation, as the insertion site of the adductor muscle only became expanded caudally, onto the lateral surface of the suspensorium (Fig. 8). However, this expansion appears to be coupled to the position of the levator operculi muscle. Whereas in C. gariepinus both muscles are well separated, with increasing adductor mandibulae size, both approach each other increasingly (Cabuy et al., 1999, fig. 9). In Clariallabes, both muscles still remain separated, whereas in Channallabes they almost touch each other. In Gymnallabes these muscles contact each other completely.

Apparently, the spatial impact of the adductor mandibulae complex on the cranial 'Bauplan' is extensive. The question that can be raised here is at what cost this has occurred. For some of the observed changes, it can be strongly suggested that they will have involved sacrifices of certain structures and/or apparatuses. (1) The reduction of the eye size, as well as its dorsal displacement, will surely influence the visual capacities. (2) Reduction of the size of the lateral bony plates implies the loss of protection of the underlying parts. (3) Narrowing of the skull may involve a reduction in strength of the braincase. (4) A caudal shift of the neurocranial insertion of the levator operculi will most certainly imply an alteration in efficiency of certain related mechanisms, especially that of the opercular mouth opening mechanism.

Catfishes in general have small eyes as an adaptation to a nocturnal and benthic life-style (Alexander, 1965; Teugels, 1996; Adriaens \& Verraes, 1997e). As a compensation, several other sensory organs are well developed, in order to survive in the murky waters. Catfishes have well developed oral barbels, which support both taste and tactile buds, and which can be moved in a controlled manner (Alexander, 1965; Singh, 1967; Ghiot, 1978; Long \& Huang, 1995). Other sensory organs also have become specialized: Weberian apparatus (Chardon, 1968); the lateral line system (Arratia \& Huaquin, 1995; Adriaens et al., 1997); the ampullary organs for electrodetection (Jakubowski, 1987; Bretschneider, Verwey \& Heuts, 1991; Whitehead, Tibbets \& Daddow, 1999). The importance of the latter sensory organs, and compared to the unimportance of visual observation is clearly shown in blind catfish (Norman, 1926; Weisel \& McLaury, 1964; Hauser, 1976; Lundberg \& Py-Daniel, 1994; Ufermann, 1998). However, in most of these catfishes, the blindness is related to a cryptic life-style (Lundberg, 1982). This presumably is also the case in Channallabes apus, as well as in other anguilliform clariids that live in murky swamps (David \& Poll, 1937; Matthes, 1964). However, the cryptic behaviour is more extreme in these species, as they live burrowed in the mud, in between roots of trees (Menon, 1951; Matthes, 1964; authors' pers. obs.).

One consequence of the dorsal expansion of the adductor mandibulae complex, is the fact that the dermal bones covering it (as observed in C. gariepinus) 
have to be reduced and thus can no longer cover and protect that muscle complex. This, however, is not favourable for a burrowing species, as burrowing behaviour is frequently associated with cranial reinforcements (Rieppel, 1996). It thus appears that in the anguilliform clariids, the resulting benefit of the enlargement of the adductor mandibulae may have overruled the reduced protection. Although the lateral bones have become much reduced in Channallabes, they still perform an important function, i.e. enclosing and protecting the infraorbital and preopercular canal.

In the anguilliform clariids, the skull becomes markedly narrow, especially in the orbitotemporal and otical region. This will most certainly have an impact on strength of that part of the braincase. It can thus be suspected that some special, reinforcing adaptations may be present. This appears to be the case in Channallabes, as well as in Gymnallabes. Compared to Clarias and Clariallabes, the degree of interdigitation of the sutures of the cranial roof bones is substantially more elaborated (Fig. 2) (Cabuy et al., 1999, fig. 3). This is not the case, however, for the skull floor bones. The central, supporting beam, formed by the prevomer, parasphenoid and basioccipital is firm, although, due to the reduction in width, the number of interdigitating processes in between these bones has decreased. A reinforcement could also be observed in the skull wall, especially at the level of the pterosphenoid. In a Clarias gariepinus specimen with a skull length of $35.8 \mathrm{~mm}$, this perichondral bone is small, only covering the ventral part of the taenia marginalis (Adriaens \& Verraes, 1998, fig. 19E). It thereby interdigitates ventrally with the parasphenoid along half of its length. In Channallabes and Gymnallabes, however, the pterosphenoid is more heavily ossified and connected to the parasphenoid along the whole of its length, even in specimens with a much smaller skull (skull length $22 \mathrm{~mm}$ ).

As mentioned, the caudal expansion of the adductor mandibulae complex can be linked to the caudal shift of the levator operculi insertion on the neurocranium. As a result, the fibres of this levator are directed much more oblique in Channallabes and Gymnallabes, compared to Clarias (Fig. 8) (Cabuy et al., 1999, fig. 9). Also, in the former two species, the opercular bone has become much more reduced, as well as tilted more in a clockwise direction. This has been suggested to be advantageous as in this way, the contraction force of the levator is presumably more efficiently transformed into a mandibular depression (Cabuy et al., 1999).

Although several arguments suggest an importance of the adductor mandibulae hypertrophy as a fitness advantage, the true nature of the resulting increase in performance of feeding or otherwise remains to be studied.

\section{Adaptations to powerful biting or simply the result of miniaturization?}

The presence of a hypertrophied adductor mandibulae complex immediately leads to the assumption that powerful biting may occur. If this is so in Channallabes, some other adaptations can also be expected related to a powerful mouth closure. Powerful biting implies a substantial increase in mechanical loading on several skeletal elements composing the biting apparatus. Those elements where adaptations can be expected are: (1) the lower jaw; (2) the upper jaw; (3) the suspensorium; (4) the neurocranium (especially at the level of adductor muscle insertion and articulation with the suspensorium). As already stated by Cabuy et al. (1999), the increasing cross-section area of the adductor muscle may require special adaptations for a more powerful mouth opening. Such adaptations, found in the protractor hyoidei, the levator operculi and the sternohyoideus, as observed in Gymnallabes, could also be observed in Channallabes (Fig. 10a) (Cabuy et al., 1999, fig. 10).

As in Gymnallabes, comparable adaptations can be observed in the lower jaw in Channallabes (Cabuy et al., 1999). The mandibulary tooth battery in Channallabes covers a larger surface of the lower jaw (relative to the total surface) compared to Clarias, as in the former the posterior teeth are situated at the anterior base of the coronoid process. This configuration is comparable to that of Clariallabes, but less pronounced than in Gymnallabes where teeth can be found on this coronoid process. The lower jaw is also markedly more slender in Clarias than in Channallabes and Gymnallabes. Also related to a more powerful bite is the size of the coronoid process. Compared to Clarias, this process is substantially higher. As discussed by Cabuy et al. (1999), this is advantageous for a powerful elevation of the lower jaw. During biting, the exertion of an asymmetrical load onto the contralateral mandibular bars will frequently occur. Consequently, the larger the contraction force of the adductor, the larger the differential loading on left and right mandibular bars may be. The observed increased symphysial surface in Channallabes, as well as Gymnallabes may thus prevent the dislocation of these bars.

The upper jaws in clariids, as well as in most other siluriforms consists of the premaxillaries and the prevomeral tooth plate. As already mentioned, the only marked difference in the premaxillaries of Channallabes and Gymnallabes involved the narrowing and distal expansion. However, whether this transformation is linked to the narrowing of the skull or to the powerful bite remains unclear at present. The prevomeral tooth plates in Channallabes and Gymnallabes appear to be fused in the middle, which they are not in Clarias gariepinus specimens of a comparable skull length (fusion occurs in larger specimens). This implies that in the former two species, teeth are present in the middle, which they are not in C. gariepinus.

As in most other teleosts, the suspensorium in clariids articulates with the neurocranium (at the level of the sphenotic and the pterotic), and suspends the lower jaw, the hyoid bar and the opercular bone. A difference, however, is the loss of the anterior articulation with the 
(a)

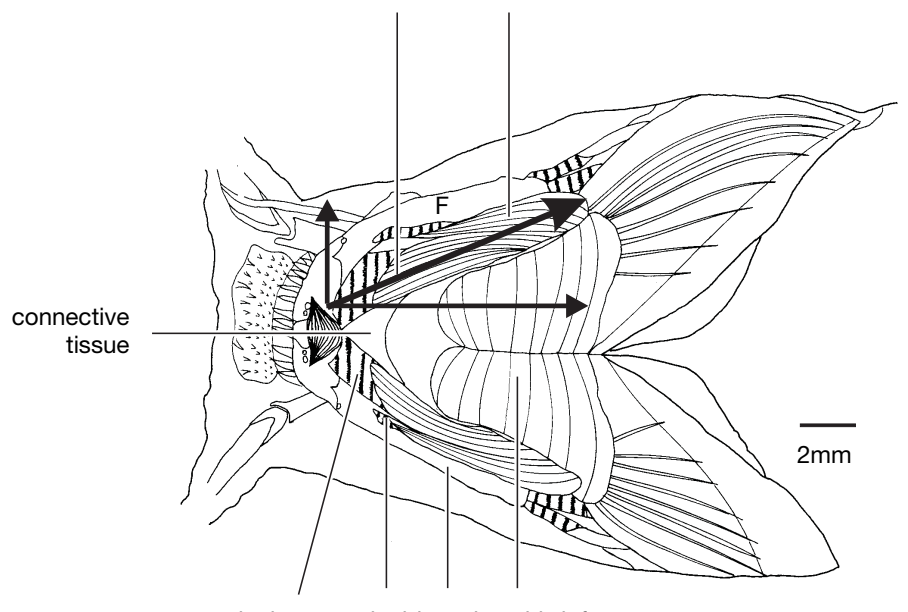

(b)

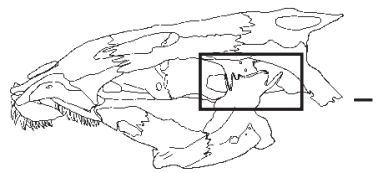

Mandibular adduction

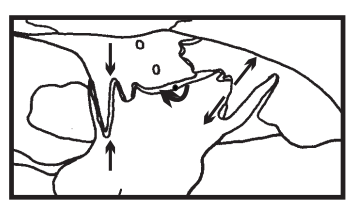

Hyoid depression

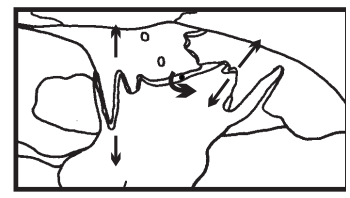

t-pr-h-d-m t-pr-h-d-I mnd m-hh-inf

Fig. 10. (a) Ventral view of the dorsal part of the hyoid protractor muscle of Channallabes apus (236 mm SL) (KMMA 175247270); F, indicates the force that can be expected on the lower jaw through contraction of this muscle; (b) schematic presentation of the pressure and pull tension at the pterotic and sphenotic processes in Channallabes apus (258 mm SL) (KMMA 175247270). mnd, mandibula; m-hh-inf, musculus hyohyoideus inferior; m-pr-h-d-l, musculus protractor hyoidei pars dorso-lateralis; m-pr-h-d-m, musculus protractor hyoidei pars dorso-medialis; t-pr-h-d-l, tendon of the m. protractor hyoidei pars dorso-lateralis; t-pr-h-d-m, tendon of the m. protractor hyoidei pars dorso-medialis.

neurocranium, as the palatine has become isolated in catfishes (Arratia \& Schultze, 1991; Arratia, 1992). This implies that the only firm connection between the suspensorium and the neurocranium occurs at the level of the hyomandibula, and consequently that all forces exerted onto the suspensorium will have to be resisted at that point. As the adductor mandibulae inserts both on the neurocranium as well as on the suspensorium, an alternating loading of this suspensorium-neurocranium articulation may be expected during contraction (Fig. 10b). In Channallabes apus, the hyomandibula bears a narrow articulatory ridge, which would be extremely disadvantageous, if it were not that both anterior and posterior to it, a series of well developed processes are present. As in other anguilliform clariids, these processes fit in between comparable processes onto the sphenotic and the pterotic (Cabuy et al., 1999). A disarticulation of the suspensorium during adductor mandibulae contraction is thus prevented.

Concerning the adaptations of the neurocranium, the presence of the processes of the sphenotic and the pterotic can be explained in analogy with the above mentioned adaptations in the suspensorium. The adaptations to the increased insertion site of the adductor mandibulae are already discussed above, as the reduced lateral skull bones have enabled the increase in attachment surface for the adductor.

As mentioned above, the Clariidae represent a group of species, in which a trend to an increasing anguilliformity is noted, which may have occurred more than once (Boulenger, 1908; Pellegrin, 1927). The elongation of the body is a process that has been observed in fishes, early tetrapods (amphibians and reptiles) and some mammals (Lande, 1978; Caroll, 1988). Together with elongation, a whole set of morphological changes has been observed, e.g. increase of the number or size of vertebrae, limblessness, reduction of the eyes, increasing rigidity of the skull, all of which are regarded as an adaptation to a fossorial habit (Withers, 1981). All of these traits also appear to be present in the anguilliform clariids. The increasing number of vertebrae has been demonstrated by Cabuy et al. (1999). Limblessness can be observed in Channallabes and Dolichallabes (Poll, $1942 a, 1957 a$ ). The reduction of the eyes has been mentioned above. Concerning the rigidity of the skull, this generally involves the braincase only, as this part needs to be reinforced due to reductions in other parts of the skull. This can be observed, for example, in fossorial reptiles - the skull transformations involve a decrease of the skull diameter and the upper temporal arch is lost (Rieppel, 1996). Analogies of both these transformations can also be observed in the anguilliform clariids - the narrowing of the skull and the reduction of the lateral skull bones (see above). It has also been stated that 'in lizards, miniaturisation is generally correlated with body elongation and limb reduction' (Rieppel, 1996). Compared to Clarias and Heterobranchus, the skulls of the anguilliform species are very small, and morphological transformations related to miniaturization are not excludible. Several cranial transformations, related to the miniaturization in lizards, involved the mouth closing apparatus. It was observed that, due to the reduced size, the size between the lower jaw and the neurocranium becomes reduced, especially in fossorial species. Hence, the jaw adductor musculature becomes obliquely oriented in those species, in order to allow the fibres to be sufficiently long (Rieppel, 1996). The elongation of the adductor muscle in the 
anguilliform clariids, as well as the increase in volume, may thus simply be an adaptation to enable an adequate biting force in the miniature skull. The burrowing habit of these species supports this hypothesis.

This miniaturization hypothesis, however, has to be taken cautiously. Within the clariids, it is a fact that the degree of cranial reductions and mandibular adductor hypertrophy is not correlated with the degree of anguilliformity. For example, the species Tanganikallabes mortiauxi is not anguilliform, but has a markedly reduced neurocranium with a large adductor mandibulae (Poll, 1943). On the other hand, Channallabes is more anguilliform than Gymnallabes, although the reduction of cranial bones is less pronounced in the former. As stated by Rieppel (1996), however, the cranial transformations in miniature lizards are coupled to the fossorial behaviour and not only to the degree of miniaturization. Thus it may be likely that the relationship between cranial adaptations and anguilliformity in Clariidae is more complex, and depends largely on the burrowing habits.

\section{Acknowledgments}

We thank the B.O.F. (G0632) and the FWO (G.0388.00) for financing this research.

\section{REFERENCES}

Adriaens, D. \& Verraes, W. (1996). Ontogeny of cranial musculature in Clarias gariepinus (Siluroidei: Clariidae): The adductor mandibulae complex. J. Morphol. 229: 255-269.

Adriaens, D. \& Verraes, W. (1997a). The ontogeny of the chondrocranium in Clarias gariepinus: trends in siluroids. J. Fish Biol. 50(6): 1221-1257.

Adriaens, D. \& Verraes, W. (1997b). Ontogeny of the hyoid musculature in the African catfish, Clarias gariepinus (Burchell, 1822) (Siluroidei: Clariidae). Zool. J. Linn. Soc. 121(3): $105-128$.

Adriaens, D. \& Verraes, W. (1997c). Ontogeny of the maxillary barbel muscles in Clarias gariepinus (Siluroidei: Clariidae), with some notes on the palatine-maxillary mechanism. J. Zool. (Lond.) 241: 117-133.

Adriaens, D. \& Verraes, W. (1997d). Ontogeny of the suspensorial and opercular muscles in Clarias gariepinus (Siluroidei: Clariidae), and the consequences for respiratory movements. Neth. J. Zool. 47(1): 61-89.

Adriaens, D. \& Verraes, W. (1997e). Some consequences of transformations in siluriform chondrocrania: a case study of Clarias gariepinus (Burchell, 1822) (Siluriformes: Clariidae). Neth. J. Zool. 47(4): 349-363.

Adriaens, D. \& Verraes, W. (1998). Ontogeny of the osteocranium in the African catfish, Clarias gariepinus (Burchell, 1822) (Siluriformes: Clariidae): ossification sequence as a response to functional demands. J. Morphol. 235(3): 183-237.

Adriaens, D., Verraes, W. \& Taverne, L. (1997). The cranial lateral-line system in Clarias gariepinus (Burchell, 1822) (Siluroidei: Clariidae): morphology and development of canal related bones. Europ. J. Morphol. 35(3): 181-208.

Alexander, R. M. (1965). Structure and function in the catfish. J. Zool. (Lond.) 148: 88-152.
Arratia, G. (1992). Development and variation of the suspensorium of the primitive catfishes (Teleostei: Ostariophysi) and their phylogenetic relationships. Bonn. zool. Monogr. 32: $1-148$.

Arratia, G. \& Huaquin, L. (1995). Morphology of the lateral line system and of the skin of diplomystid and certain primitive loricarioid catfishes and systematic and ecological considerations. Bonn. zool. Monogr. 36: 5-110.

Arratia, G. \& Schultze, H.-P. (1991). Palatoquadrate and its ossifications: development and homology within osteichthyans. J. Morphol. 208: 1-81.

Barel, C. D. N. (1984). Form-relations in the context of constructional morphology: the eye and suspensorium of lacustrine cichlidae (Pisces, Teleostei). Neth. J. Zool. 34(4): 439-502.

Benton, M. J. (1997). Vertebrate palaeontology. London: Chapman \& Hall.

Bock, W. J. \& Shear, Ch. R. (1972). A staining method for gross dissection of vertebrate muscles. Anat. Anz. 130: 222-227.

Boulenger, G. A. (1908). A revision of the African silurid fishes of the subfamily Clariinae. Proc. Zool. Soc. 2: 1062-1096.

Boulenger, G. A. (1911). Catalogue of the fresh-water fishes of Africa in the British Museum (Natural History), 2. London: British Museum (Natural History).

Bretschneider, F., Verway, J. \& Heuts, P. (1991). Functioning of catfish electroreceptors: input impedance and stimulus efficiency. Comp. Biochem. Physiol. 99A(3): 295-299.

Cabuy, E., Adriaens, D., Verraes, W. \& Teugels, G. G. (1999). Comparative study on the cranial morphology of Gymnallabes typus (Siluriformes: Clariidae) and their less anguilliform relatives, Clariallabes melas and Clarias gariepinus. J. Morphol. 240: $169-194$.

Caroll, R. L. (1988). Vertebrate paleontology and evolution. San Francisco: W. H. Freeman.

Chardon, M. (1968). Anatomie comparée de l'appareil de Weber et des structures connexes chez les Siluriformes. Ann. Mus. Roy. Afriq. Cent. 169: 1-277.

Daget, J. I. (1964). Le crane des téleostéens, I. Origine et mise en place des tissus squelettogènes chez l'embryon. Mésomésenchyme et ectomésenchyme. Mém. Mus. nat. Hist. nat., A. Zool. 31(2): 164-340.

David, L. (1935). Die Entwicklung der Clariiden und ihre Verbreitung. Rev. Zool. Bot. Afric. 28: 77-147.

David, L. \& Poll, M. (1937). Contribution à la faune ichthyologique du Congo Belgique: collections du Dr. H. Schouteden (1924-1926) et d'autres récolteurs. Ann. Mus. Congo, Zool. I 3(5): 189-294.

Diogo, R., Vandewalle, P. \& Chardon, M. (1999). Morphological description of the cephalic region of Bagrus docmac, with a reflection on Bagridae (Teleostei: Siluriformes) autapomorphies. Neth. J. Zool. 49(3): 207-232.

Fink, S. V. \& Fink, W. L. (1996). Interrelationships of Ostariophysans fishes (Teleostei): 209-249. London: Academic Press.

Ghiot, F. (1978). The barbel movements of three South American pimelodid catfishes. Zool. Anz. 56: 395-401.

Gosline, W. A. (1975). The cyprinid dermosphenotic and the subfamily Rasborinae. Occ. Pap. Mus. Zool. Univ. Mich. 673: $1-13$.

Greenwood, P. H. (1961). A revision of the genus Dinotopterus Blgr. (Pisces, Clariidae) with notes on the comparative anatomy of the suprabranchial organs in the Clariidae. Bull. Brit. Mus. Nat. Hist. (Zool.) 7(4): 217-241.

Hanken, J. \& Wassersug, R. (1981). The visible skeleton. A new double-stain technique reveals the native of the 'hard' tissues. Funct. Photogr. 16: 22-26.

Hauser, W. J. (1976). A blind channel catfish, Ictalurus punctatus. Copeia 3: 612-613.

Jakubowski, M. (1987). Ultrastructure of the ampullary electroreceptory organs in Silurus glanis (Pisces). Z. Mikrosk.-Anat. Forsch. Leipzig 101(3): 461-472. 
Lande, R. (1978). Evolutionary mechanisms of limb loss in tetrapods. Evolution 32: 73-92.

Liem, K. F. (1980). Air ventilation in advanced teleosts: biomechanical and evolutionary aspects. In Environmental physiology of fishes: 57-91. Ali, M. A. (Ed.). New York: Plenum Publishing Corporation.

Long, T. C. \& Huang, Y. M. (1995). Recording of the taste response of maxillary barbel isolated from walking catfish, Clarias leather. Acta Zool. Sin. 41(2): 158-166.

Lundberg, J. G. (1982). The comparative anatomy of the toothless blindcat, Trogloglanis pattersoni Eigenmann, with a phylogenetic analysis of the Ictalurid catfishes. Misc. Pub. Mus. Zool. Univ. Mich. 163: 1-85.

Lundberg, J. G. \& Py-Daniel, L. H. R. (1994). Bathycetopsis oliveirai, gen. et sp. nov., a blind and depigmented catfish (Siluriformes: Cetopsidae) from the Brazilian Amazon. Copeia 2: $381-390$.

Matthes, H. (1964). Les Poissons du Lac Tumba et de La Région D'Ikela. PhD thesis, Nijmegen, Netherlands.

Menon, A. G. K. (1951). Distribution of clariid fishes, and its significance in zoogeographical studies. Proc. Nat. Inst. Sci. Ind. 4(17): 291-299.

Norman, J. R. (1926). A new blind catfish from Trinidad, with a list of the blind cave-fishes. Ann. Mag. Nat. Hist. 18(106): 324-331.

Pellegrin, J. (1927). La disparition des nageoires paires chez les poissons Africains du groupe des clariinés. Ann. Sci. Nat. (Zool.) Paris 10: 209-222.

Poll, M. (1942a). Description d'un genre nouveau de Clariidae originaire de Congo Belge. Rev. Zool. Bot. Afric. 36(1): 96-100.

Poll, M. (1942b). Note sur l'ostéologie de Dolichallabes microphthalmus Poll et remarques sur l'évolution des Clariidae. Ann. Soc. Roy. Zool. Belg. 73(3-4): 222-235.

Poll, M. (1943). Description du Tanganikallabes mortiauxi, gen. nov., sp. n., de la famille des Clariidae. Rev. Zool. Bot. Afric. 37(1-2): 126-133.

Poll, M. (1957a). Les genres des poissons d'eau douce de l'Afrique. Ann. Mus. Roy. Afriq. Cent. IN-8 54: 1-191.

Poll, M. (1957b). Redescription du Gymnallabes tihoni Poll 1944, Clariidae microphthalme du Stanley-Pool (Congo Belge). Rev. Zool. Bot. Afric. 55(3-4): 237-248.

Poll, M. (1977). Les genres nouveaux Platyallabes et Platyclarias comparés au genre Gymnallabes GTHR. Synopsis nouveau des genres de Clariidae. Bull. Classe Sci. 5(63): 122-149.
Rieppel, O. C. (1996). Miniaturization in tetrapods: consequences for skull morphology. In Miniature vertebrates: 15-45. Miller, P. J. (Ed.). Oxford: Clarendon Press.

Singh, B. R. (1967). Movements of barbels in some siluroid fishes. Zool. Anz. 178(5-6): 402-412.

Skelton, P. (1993). A complete guide to the freshwater fishes of Southern Africa. Zimbabwe: Southern Book Publishers Ltd.

Teugels, G. G. (1986). A systematic revision of the African species of the genus Clarias (Pisces, Clariidae). Ann. Mus. Roy. Afriq. Cent. 247: 1-199.

Teugels, G. G. (1996). Taxonomy, phylogeny and biogeography of catfishes (Ostariophysi, Siluroidei): an overview. Aqu. Liv. Res. 9(Hors série): 9-34.

Teugels, G. G., Denayer, B. \& Legendre, M. (1990). A systematic revision of the African catfish genus Heterobranchus GeoffroySaint-Hilaire, 1809 (Pisces, Clariidae). Zool. J. Linn. Soc. 98: 237-257.

Teugels, G. G., Reid, G. M. \& King, R. P. (1992). Fishes of the Cross River Basin (Cameroon - Nigeria): Taxonomy, Zoogeography, Ecology and Conservation. Ann. Mus. Roy. Afriq. Cent. 266: 1-132.

Travers, R. A. (1984). A review of the Mastacembeloidei, a suborder of synbranchiform teleost fishes. Part I: Anatomical descriptions. Bull. Brit. Mus. Nat. Hist. (Zool.) 46(1): 1-133.

Ufermann, A. (1998). Ein weiterer blinder Ancistrus. Deutz Aqu. Terr. Zeit. 51(5): 278.

Verraes, W. (1981). Theoretical discussion on some functionalmorphological terms and some general reflexions on the explanations in biology. Acta Biotheor. 30: 255-273.

Vetter, B. (1878). Untersuchungen zur vergleichende Anatomy der Kiemen- und Kiefermuskulatur der Fische II. Jena Z. Naturw. 12(3): 431-550.

Weisel, G. F. \& McLaury, E. L. (1964). Blind catfish (Ictalurus nebulosus) from Dog Lake, Oregon. Copeia 4: 687-690.

Whitehead, D. L., Tibbetts, I. R. \& Daddow, L. Y. M. (1999). Distribution and morphology of the ampullary organs of the salmontail catfish, Arius graeffei. J. Morphol. 239: 97-105.

Winterbottom, R. (1974). A descriptive synonymy of the straited muscles of the Teleostei. Proc. Acad. Nat. Sci. Philad. 125(12): 225-317.

Withers, P. C. (1981). Physiological correlates of limblessness and fossorial lizards. Copeia 1: 197-204. 